\title{
Seismotectonic content by the source parameters of the 10 June 2012 Ölüdeniz-Fethiye (Dodecanese Islands) $M w 6.1$ earthquake and aftershocks (southwestern Turkey)
}

\author{
Bülent Doğan • T. Serkan Irmak • Ahmet Karakaş • Doğan Kalafat
}

Received: 23 July 2014/Accepted: 24 February 2015/Published online: 5 March 2015

(C) Akadémiai Kiadó 2015

\begin{abstract}
A detailed source and rupture process analyzes of the 10 June 2012 ÖlüdenizFethiye (Dodecanese Islands; $M w$ 6.1) earthquake has been carried out using inversion of both complex body waves and strong ground motion records. The rupture starting from the hypocenter propagated gradually to the southwest. The main rupture is modeled by a main asperity located $2-3 \mathrm{~km}$ beneath the hypocenter and two small asperities. The size of the effective source area is about $24 \times 12 \mathrm{~km}$, the rupture duration was approximately $12 \mathrm{~s}$ and the total seismic moment was estimated to be $1.955 \times 10^{18} \mathrm{Nm}$. Continuation of compression from the Hellenic Arc to the southeast part of Fethiye Gulf in the north developed many active faults with complex geometries in the region. According to the stress field obtained from the focal mechanism solutions of the 10 June 2012 Fethiye (Dodecanese Islands; $M w$ 6.1) earthquake and $M \geq 3.5$ earthquakes which occurred in Fethiye Gulf, the region between Fethiye Gulf and Rhodes Basin was deformed by the NW-SE oriented extension. (T- $\sigma 3)$ principal stress axis is dominant in the region. Additionally, NNW-SSE compression (P- $\sigma 1)$ in further southwest of Fethiye Gulf contributed to forming normal and strike-slip faults. Continuation of the NE-SW trending thrust faults located from the west limb of the Hellenic Arc to the southeast of Fethiye Gulf caused deformation in the region due to the seismotectonic model of the region. Both, normal faulting related to the "pure extension" occurred after the compression, and strike-slip
\end{abstract}

B. Doğan $(凹) \cdot$ A. Karakaş

Department of Geological Engineering, Kocaeli University, 41040 Kocaeli, Turkey e-mail:doganb3@yahoo.com; bulentd@kocaeli.edu.tr

A. Karakaş

e-mail: akarakas@kocaeli.edu.tr

T. Serkan Irmak

Seismology Section, Department of Geophysical Engineering, Kocaeli University, 41040 Kocaeli, Turkey

e-mail: serkan_irmak@yahoo.com; irmakts@kocaeli.edu.tr

D. Kalafat

Kandilli Observatory and Earthquake Research Institute, Boğaziçi University, 34684 Istanbul, Turkey e-mail: kalafato@boun.edu.tr 
faulting associated with the "transtension", have been expressed by the spatial positions of the principal stress axes in the study area.

Keywords Fethiye (Dodecanese Islands; $M w$ 6.1) earthquake $\cdot$ Focal mechanism $\cdot$ Stress field $\cdot$ Extension $\cdot$ Transtension $\cdot$ Seismotectonic model

\section{Introduction}

The Anatolian plate, located in the Alpine orogenic belt, is one of the important regions in terms of earthquake potential in the world (Dewey et al. 1973; Okay and Tüysüz 1999). The closure of the north and south branches of the Tethys Ocean created the Alpine orogenic belt (Şengör and Yılmaz 1981; Okay and Tüysüz 1999). Several continental scale structural elements which deformed the Plio-Quaternary deposits after the Oligo-Miocene and generated many historical and instrumental earthquakes developed in this region (Şengör et al. 1985; Barka 1992). The collision of the Arabian and African plates with the Anatolian plate in the east and subduction dominated the tectonic regime in the west and created these major structural elements. One of these main structural elements is the BitlisZagros Suture Zone developed by the continental-continental collision, and the other one is the Hellenic Arc created by the subduction in the Mediterranean Sea and southern Europe (Fig. 1a, Jolivet and Faccenna 2000). The Anatolian plate currently rotates anticlockwise towards the west within the tectonic framework of the region (Reilinger et al. 2006). The movement of the African plate towards the north developed thrust faults along the Hellenic Arc in the Mediterranean oceanic lithosphere and presently earthquakes occur on and around these thrust faults (Soloviev et al. 2000; Papadopoulos 2001; Guidoboni and Comastri 2005; Sbeinati et al. 2005; Ambraseys 2009; Guidoboni and Ebel 2009).

The continuation of the Hellenic Arc subduction created left lateral strike-slip faults with normal component, such as Pliny and Strabo (Le Pichon et al. 1982; Chaumillon and Mascle 1995). Correspondingly, the southern Aegean region confronted an extensional tectonic regime after the development of the arc. The movement of the African oceanic plate, which developed the Hellenic Arc, towards the north created the Isparta angle (IA) which has east and west limbs on the continental plate in the north of Antalya (see Fig. 1a). The sinistral NE-SW trending Fethiye-Burdur Fault Zone (FBFZ) with an extensional component, located in the western limb of the Isparta Angle, is the continuation of the NNE-SSW trending Pliny-Strabo fault system on land (Glover and Robertson 1998; Bozkurt 2001). Very low frequency electromagnetic (VLF) study was carried out on the FBFZ in a NW-SE direction. A fault zone reaching up to $40 \mathrm{~m}$ depth with high conductivity was detected in NW-SE sections (Gürer et al. 2004). The study area extends from Rhodes Island and vicinity in the southwest of the Isparta Angle to Fethiye Gulf northeast of Rhodes Island (see Fig. 1a).

A moderate earthquake occurred on 10 June 2012 at 12:44 (UTC) in Fethiye Gulf (Dodecanese Islands; $M w$ 6.1) in the southwest of Turkey. The hypocenter determined by Kandilli Observatory and Earthquake Research Institute (KOERI) is located at $36.4542^{\circ} \mathrm{N}$, $28.9047^{\circ} \mathrm{E}$, in a depth of $19 \mathrm{~km}$ (KOERI 2012). The hypocenter is situated close to Fethiye Gulf. A total number of seven persons were slightly injured, mainly by jumping from buildings.

The purpose of this study is to evaluate the 10 June 2012 Fethiye $M w 6.1$ earthquake kinematically and seismotectonically. For this purpose, focal mechanism of the fault planes 
of Fethiye earthquake main shock and aftershocks were determined. Additionally, principal stress axes directions of Fethiye earthquake were compared with the focal mechanisms of other earthquakes of this area, and an approximation was made for the origin of the active crust deformation in the region. Geographical distributions of the principal stress vectors acquired from the previous earthquakes, the directions of the stresses based on recent GPS velocities and the block movement vectors based on the magnetisms obtained from geological samples are comparatively evaluated in order to define kinematics and seismotectonic features of the earthquake. The source parameters of the 18 earthquakes (11 of them are aftershocks with $3.5<M<5.3$ ) were derived by using the first motion polarities of regional $\mathrm{P}$ waves collected by KOERI. Additionally, the focal mechanism of three aftershocks reported by the Disaster and Emergency Management Presidency (DEMP) of Turkey, two earthquakes reported by Kalafat et al. (2009), and six earthquakes reported by Mediterranean Network (MEDNET) were used for the present-day stress analysis. Hence a total number of 29 earthquakes including the main shock were used in the analysis. In general, teleseismic body waves contain information on the overall moment release rate and the depth range of the rupture area, while strong ground motion data contain most of the information about detailed slip process in the source area. Therefore, to estimate a detailed and stable source process, it is important to use both teleseismic body waves and strong ground motion data (Yagi 2004). Thus the source rupture processes of Fethiye $M w$ 6.1 earthquake were analyzed using joint inversion of the teleseismic $P$ - and $S H$-waves as well as strong ground motion records collected by the Data Management Center of the Incorporated Research Institutions for Seismology (IRIS-DMC) and DEMP stations respectively.

\section{Bathymetry and GPS}

The western Anatolian, southern Aegean and western Mediterranean lithospheres move on average $25 \mathrm{~mm} \mathrm{year}^{-1}$ anticlockwise in relation to the Eurasian plate (Clarke et al. 1998; McClusky et al. 2000; Ayhan et al. 2002; Meade et al. 2002). While the subduction rate is $18 \mathrm{~mm}$ year $^{-1}$ along the Hellenic Arc in the south of the Mediterranean, the Pliny-Strabo fault located in the north of the Hellenic Arc and Fethiye-Burdur fault yield a $10 \mathrm{~mm}_{\text {year }}{ }^{-1}$ movement defined by the Global Positioning System (GPS) (Reilinger et al. 2006). Ganas and Parsons (2009) indicate that the movement of the Aegean Plate towards $\mathrm{S} 35^{\circ} \mathrm{W}$ direction with $33 \mathrm{~mm}$ year $^{-1}$ and the movement of the African (Nubian) Plate in the south towards $\mathrm{N} 10^{\circ} \mathrm{W}$, direction with $5 \mathrm{~mm}$ year ${ }^{-1}$ characterize more likely a continental thrust rather than a subduction (see Fig. 1a). Kreemer and Chamot-Rooke (2004) proposed two different strain models, A and B, based on GPS data. Model A is based on matching the GPS vectors with the model velocities (Fig. 1b). In this model; the compression vector magnitude decreases and becomes equal to the tension vector in the north around Fethiye Gulf, while the compression vector around the Hellenic Arc in the western Mediterranean Region is larger than the tension vector. Model B is constituted by adding the constraints coming from the active faulting to the inversion of the GPS velocity data set. In this model, the strikes of the mountain tracks were used to define the boundaries of tectonic areas. The compression direction obtained from the strain ratios is compatible with the striking of the seamount tracks. Additionally, the compression component of the regional strain ratios in the south of the study area is greater than the extension component in model B (Fig. 1c). 
Fig. 1 a Map of the active faults that border all of the plates and the location of the study area (Ten Veen 2004; Ten Veen et al. 2009). SCT South Cretan Trough, ST Strabo Trench, PT Pliny Trench, $R B$ Rhodes Basin, $A N$ Anaxagoras Mountain, $A M$ Anaximander Mountain, FBFZ Fethiye-Burdur Fault Zone, $M M$ Menderes Massif, $A G$ Antalya Gulf, $A B$ Aksu Basin, $E B$ Esençay Basin. If the Eurasian plate is assumed fix, the Arabian and African Plates move relatively to the north, while the Anatolian plate moves with about $20 \mathrm{~mm} /$ year GPS velocity to the west, the study area is marked by a colored square. b The study area with the epicenter of the 10 June 2012 Fethiye $M w 6.1$ earthquake (red star) and the strain ratios according to Model A of Kreemer and Chamot-Rooke (2004). c The epicenter of the earthquake with respect to the fixed position of the Eurasian Plate and values of GPS velocity vectors (red arrows) and paleomagnetic declination of the neotectonic units (green arrows) in the vicinity of the epicenter, Strain ratios according to Model B of Kreemer and Chamot-Rooke (2004). The square indicates the study area. This was indicated in the caption

The bathymetry contours range between 1000 and $3000 \mathrm{~m}$ in the vicinity and farther south of the 10 June 2012 Fethiye $M w 6.1$ earthquake epicenter. The bottom of the Rhodes Basin further south is the deepest point $(4000 \mathrm{~m})$ in the bathymetry of the region (Woodside et al. 2000; Kontogianni et al. 2002). The Rhodes Basin is located in the southwest of the epicenter. Some important bathymetric features in the region are the Pliny trench located $200 \mathrm{~km}$ south of the epicenter, the Strabo trench located $100 \mathrm{~km}$ southeast of the Pliny trench, and the Anaximander and Anaxagoras seamounts located in the southeast of the Rhodes Basin. The south border of the seamounts is associated with the Hellenic Arc (Hall et al. 2009).

The compressional system that has developed the Hellenic Arc around Rhodes Island and south of the island creates a rotation, especially in the northwest of the Mediterranean lithosphere that has been the part of the African oceanic plate in the Neotectonic period (Plio-Quaternary). When this rotation is correlated with the paleomagnetism declinations determined from the samples taken from the Pliocene deposits in Rhodes Island (Fig. 1c). It is deduced that the motion of the plate is mainly anticlockwise and partially clockwise and the region is deformed by a complex compression and rotation (Duermeijer et al. 2000; Van Hinsbergen et al. 2005; Piper et al. 2010).

\section{Seismology}

Numerous earthquakes with $M \geq 3$ have occurred along the Hellenic Arc in the Mediterranean Sea (Y1lmaztürk and Burton 1999; Pondrelli et al. 2002; Kreemer and Chamot-Rooke 2004; Taymaz et al. 2004; Tan and Taymaz 2006; Yolsal-Çevikbilen and Taymaz 2012; Irmak 2013). Also some moderate $(4 \leq M \leq 6)$ and large $(M \geq 6)$ earthquakes took place during the historical and instrumental periods in the north of the Hellenic Arc, around Rhodes Island and in the vicinity of Fethiye $M w 6.1$ earthquake (Papazachos 1996; Papazachos et al. 2000). The most important earthquakes were the 24 April 1957 ( $M$ 6.8) and 25 April 1957 (M 7.1) earthquakes with an average $40 \mathrm{~km}$ hypocenter depth (Papazachos and Delibasis 1969; McKenzie 1972; Papazachos 1996; Ebeling et al. 2012). Other earthquakes in this region have occurred in around $20 \mathrm{~km}$ hypocenter depths (Kreemer and Chamot-Rooke 2004; Chamot-Rooke et al. 2005).

\subsection{Source parameters of the earthquakes}

It is essential to define the source parameters of the earthquakes accurately. Defining the source parameters accurately allows us to understand the source mechanism of the 


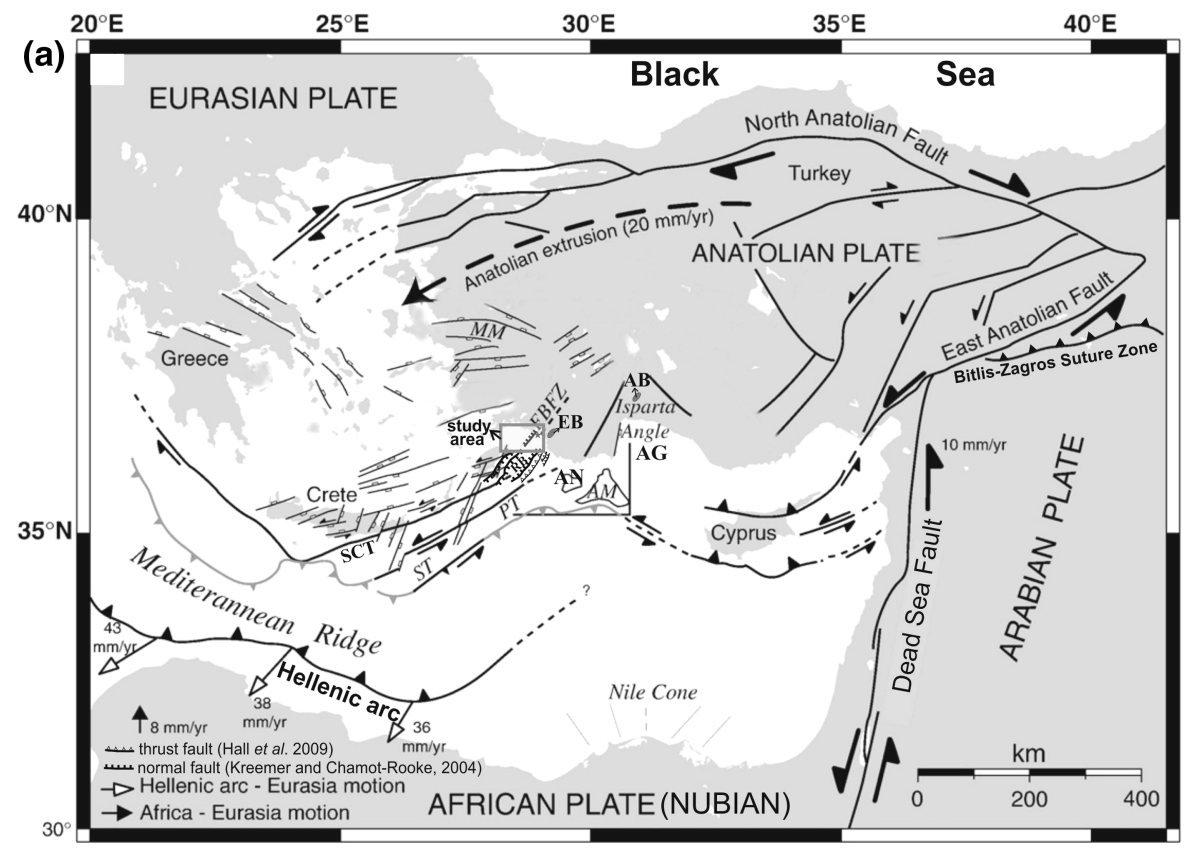

(b)

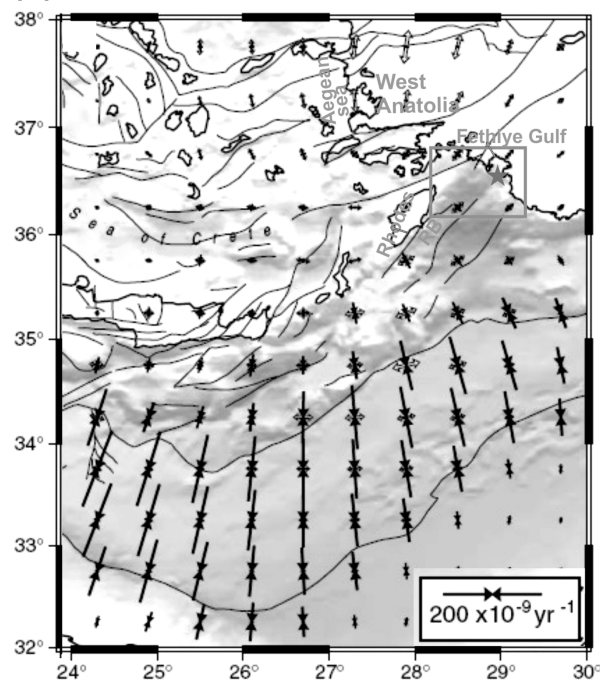

(c)

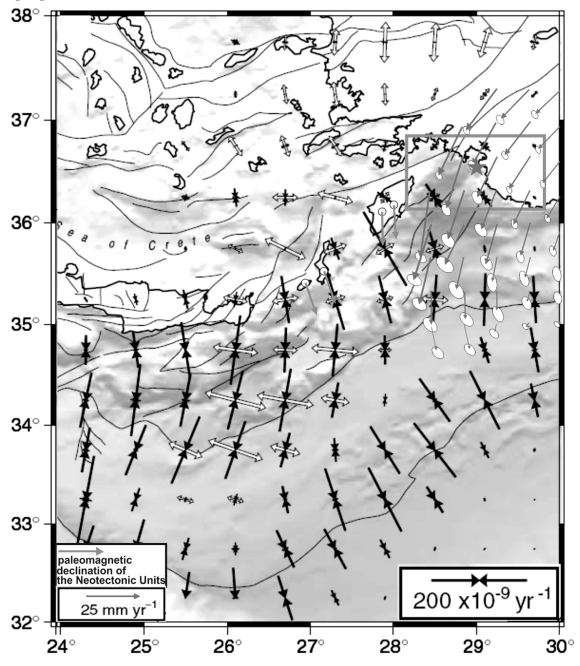

earthquake, the tectonic setting as well as the present-day stress situation better, to develop an effective seismic hazard assessment. Therefore, as a first step, fault plane solutions were calculated by utilizing $P$-wave polarities running the FOCMEC programs (Snoke et al. 1984) for the main shock and other 17 analyzed earthquakes (11 of them are aftershocks of the 10 June 2012 Fethiye $M w 6.1$ earthquake). All available polarities were carefully read from national seismic stations as well as additional Greek and GEOFON stations, which were used to obtain superior azimuthal coverage (Fig. 2a). The number of stations with 


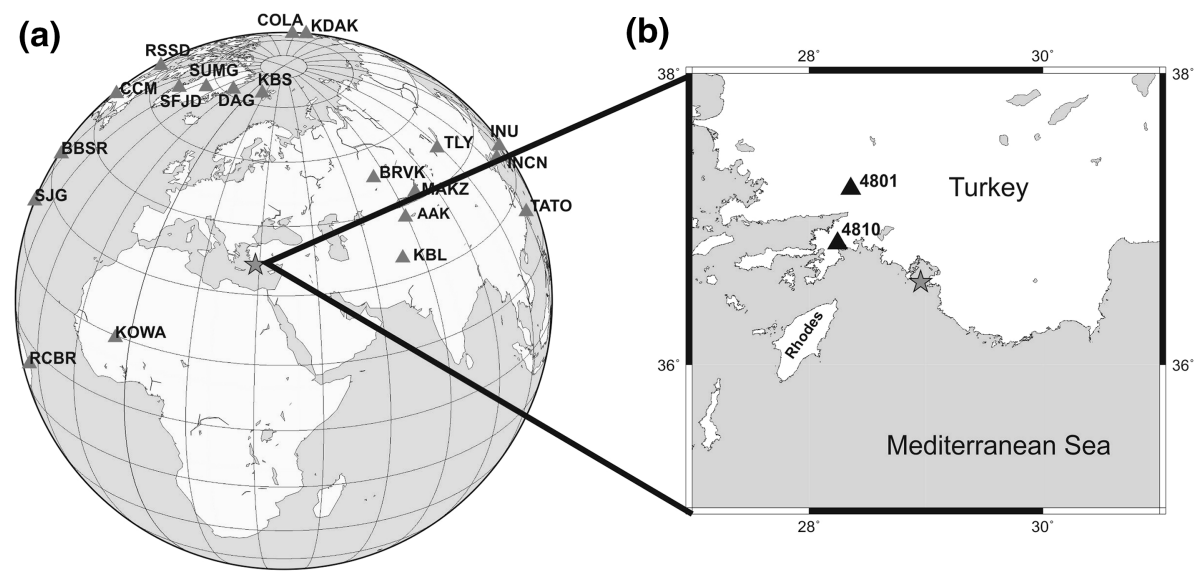

Fig. 2 a Map of teleseismic and $\mathbf{b}$ strong ground motion stations which were used in the joint inversion

unambiguous first arrival polarities varies from earthquake to earthquake, but, events with fewer than 10 clear polarity readings were discarded, as were those with ambiguous polarities. The take off angles were reported by Kandilli Observatory and Earthquake Research Institute-National Earthquake Monitoring Center (KOERI-NEMC). The possible nodal planes which agree with the first motion polarities were searched, running the FOCMEC program (Snoke et al. 1984). The $P$-waves were converted to displacement in order to see the $\mathrm{P}$-wave onsets better due to the low $\mathrm{S} / \mathrm{N}$ ratio. Assuming the double-couple model for the seismic point source, $P$-polarities on displacement seismograms were then read. Polarity errors may be caused by low $\mathrm{S} / \mathrm{N}$ ratio at stations near nodal planes, so called 'mislocations', or by structural heterogeneity, biasing calculation of azimuth and take off angle and aliasing effects due to signal frequencies being higher than the sampling rate (Scherbaum 1994). However, no polarity error was allowed in the solutions. Events with multiple acceptable solutions, indicating different mechanisms, or with faulting parameters uncertainties exceeding $20^{\circ}$ were not reported in this study.

\subsection{Slip distribution model of the main shock}

Broadband data with vertical components of teleseismic $P$ - and $S H$-waves were retrieved from the Data Management Center of the Incorporated Research Institutions for Seismology (IRIS), selecting 22 stations with epicentral distances between $30^{\circ}$ and $100^{\circ}$ (Fig. 2b). The data windowed at $60 \mathrm{~s}$ starting at $10 \mathrm{~s}$ before $P$-wave arrival and were integrated to displacement and band-pass filtered between 0.002 and $1.0 \mathrm{~Hz}$. The data set was obtained from the KOERI catalog (http://www.koeri.boun.edu.tr/scripts/ Sondepremler.asp). We also selected six components of strong motion data obtained from two accelerometer stations of DEMP. The locations of these near-field stations are shown in Fig. 2a. The acceleration data were windowed for $60 \mathrm{~s}$, starting $10 \mathrm{~s}$ before the first motion, band-passed between 0.01 and $0.5 \mathrm{~Hz}$, and numerically integrated to ground displacement with a sampling time of $0.5 \mathrm{~s}$.

To estimate a detailed and stable source process, it is important to use both teleseismic body waves and strong ground motion data. The international seismological centers determined the hypocenter depth of the main shock on 10 June 2012 Fethiye earthquake to be 
between 18 and $30 \mathrm{~km}$. The accuracy of earthquake depth estimates increases with availability of near-field stations. Therefore, two accelerometer stations of DEMP records have been used in addition to broadband IRIS stations for obtaining depth and spatiotemporal slip distribution of the earthquake. The first motion polarity solution of the main shock represents the initial movement at the focus whereas the moment tensor solution represents source parameters of the large slip area. However, the fault model based on the moment tensor solution is more appropriate than the fault model estimated from the focal mechanism by the initial $\mathrm{P}$-wave polarity, since the focal mechanism by the $P$-wave polarities represents only the initial rupture process during the main shock. Thus, the focal mechanisms obtained by the moment tensor solution of the inversion method were used. The centroid moment tensor solution of the earthquake reported by Harvard University (HRV) is very similar to the first motion solution and the separation of the stations is more realistic (Fig. 3). Therefore, we chose the centroid moment tensor solution of the earthquake reported by HRV. Indeed, several source inversion studies by using teleseismic data assumed the fault models based on the moment tensor solutions (e.g. Kikuchi et al. 2000; Yagi 2004; Yagi et al. 2004).

Applying a multi-time window inversion to the data, the spatio-temporal distributions of fault slip have been estimated in previous studies (e.g. Yoshida 1992; Hartzell and Heaton 1983). We used an inversion code originally given by Yoshida et al. (1996) and later developed by Yagi et al. (2003). A single fault plane was assumed for the waveform analysis to obtain the slip distribution. The size of the fault plane was defined by $50 \times 25 \mathrm{~km}$ and the rupture was assumed to start at the determined hypocenter of the main shock. According to the right hand rule, the strike and dip direction were assumed to be $206^{\circ}$ and $79^{\circ} \mathrm{WSW}$ respectively by HRV solution. We assumed that all points in a subfault have the same Green's function as the center of a sub-fault. We calculated the Green's functions for the teleseismic body waves using the method proposed by Kikuchi and Kanamori (1991) for teleseismic body waveforms and using the discrete wave number method developed by Kohketsu (1985) for strong ground motion. The sampling time of the Green's function was set at $0.5 \mathrm{~s}$. The layered seismic velocity structures used in the synthetics are given in Table 1. For a near-structure, we adopted the velocity model of Akyol et al. (2006) with small modifications and with an additional layer of $1.5 \mathrm{~km}$ thick water.

We solved the least squares problem with a positivity constraint on the model parameters using the non-negative least squares (NNLS) algorithm of Lawson and Hanson (1974). For discretization in space, the fault plane was divided into 10 sub-faults in the strike direction and into 5 sub-faults in the dip direction (making a total of 50 sub-faults with an area of $5 \times 5 \mathrm{~km}$ ). The slip rate function of each sub-fault is expanded into a series of two triangle functions with a rise time of $1.5 \mathrm{~s}$. The rupture velocity of $3.0 \mathrm{~km} / \mathrm{s}$ was selected by trial and error; this determines the initiation time of the basis function at each sub-fault. To suppress instability or excessive complexity, a smoothing constraint was introduced to the differences in moment release.

\section{Results}

The results for the slip distribution obtained by the joint waveform inversion are shown in Fig. 4. Figure 5 shows the observed and synthetic waveforms. Overall matching between the synthetics and observed waveforms is quite good. The depth of the earthquake was computed to be $24 \mathrm{~km}$ (Fig. 6). The total seismic moment is calculated to be 

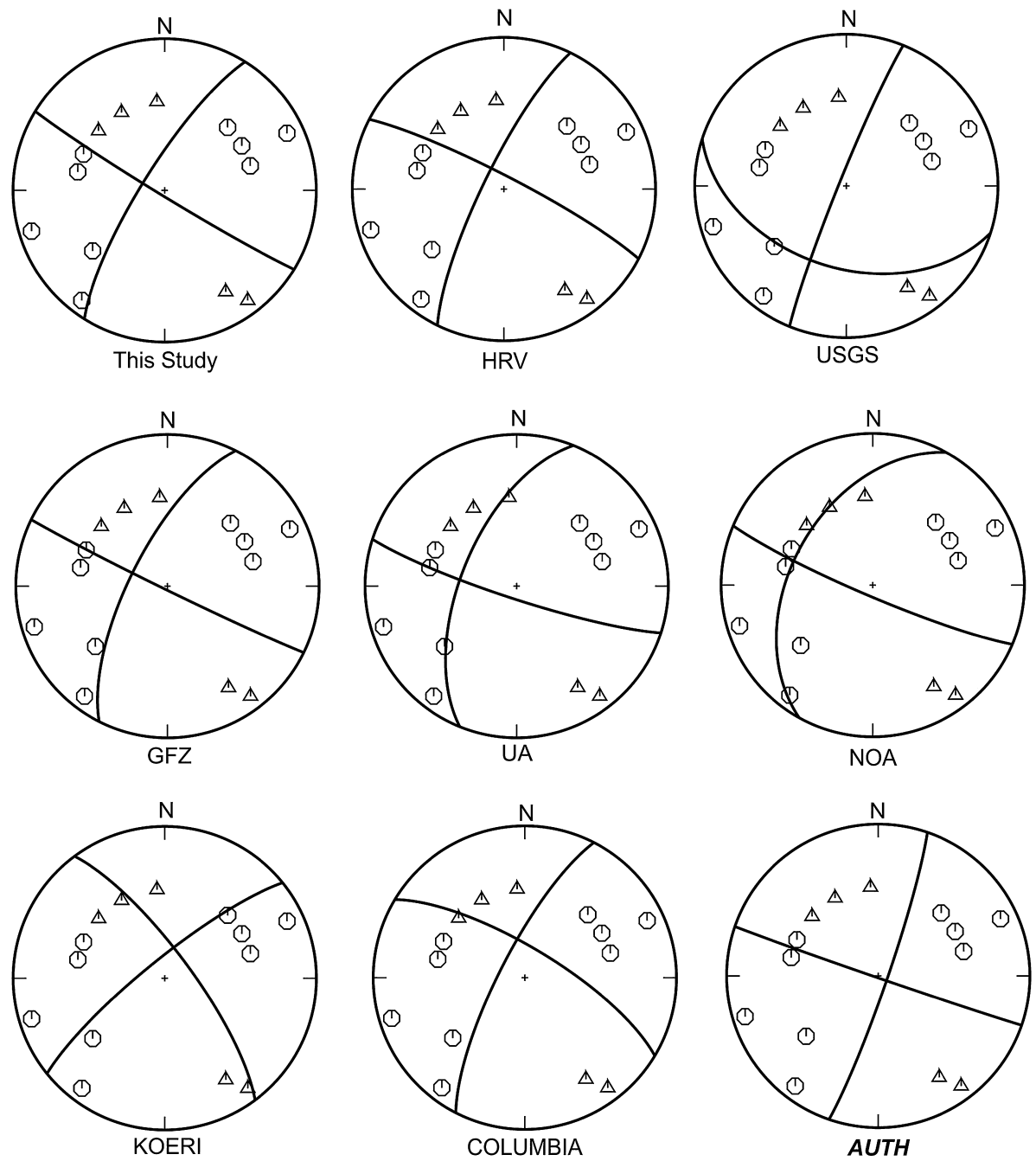

\section{(1) Compression $\triangle$ Dilatation}

Fig. 3 Representation of the focal mechanism solution of 10 June 2012 Fethiye $M w 6.1$ earthquake reported by different agencies using first motion polarities. The best match belongs to the HRV solution. AUTH Aristotle University of Thessaloniki, COLUMBIA Columbia University, GFZ Deutsches GeoForschungs Zentrum-Potsdam, HRV Harvard University, KOERI Kandilli Observatory and Earthquake Research Institute, NOA National Observatory of Athens, UA University of Athens, USGS United States Geological Survey. (http://www.emsc-csem.org/Earthquake/mtfull.php?id=272709) (EMSC 2012)

$1.955 \times 10^{18} \mathrm{Nm}(M w 6.1)$, close to the seismic moment of $1.6 \times 10^{18} \mathrm{Nm}$ derived by Deutsches GeoForschungsZentrum GFZ, Germany, $1.84 \times 10^{18} \mathrm{Nm}$ calculated by HRV and $2.0 \times 10^{18} \mathrm{Nm}$ computed by United States Geological Survey (USGS) (http://www. emsc-csem.org/Earthquake/mtfull.php?id=272709) (EMSC 2012). The size of the effective 
Table 1 Adopted and modified layered crustal seismic velocity structure (Akyol et al. 2006)

$\alpha, \beta=P$ and $S$ wave velocities, $\rho=$ density, $d=$ thickness

\begin{tabular}{lllc}
\hline Structures & & & \\
\hline$\alpha(\mathrm{km} / \mathrm{s})$ & $\beta(\mathrm{km} / \mathrm{s})$ & $\rho\left(\mathrm{kg} / \mathrm{m}^{3}\right)$ & $\mathrm{d}(\mathrm{km})$ \\
\hline Source region & & & \\
1.50 & 0.00 & $1.00 \times 10^{3}$ & 1.5 \\
5.21 & 3.01 & 2.65 & 5.0 \\
6.00 & 3.47 & 2.87 & 10.0 \\
6.25 & 3.61 & 2.95 & 6.0 \\
6.43 & 3.72 & 3.15 & 8.0 \\
7.80 & 4.51 & 3.30 & - \\
Receiver region & & & 15.0 \\
5.57 & 3.36 & 2.65 & 18.0 \\
6.50 & 3.74 & 2.87 & - \\
8.10 & 4.68 & 3.30 & \\
\hline
\end{tabular}

(a)

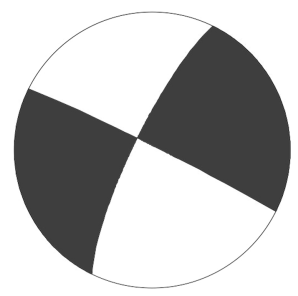

(b)

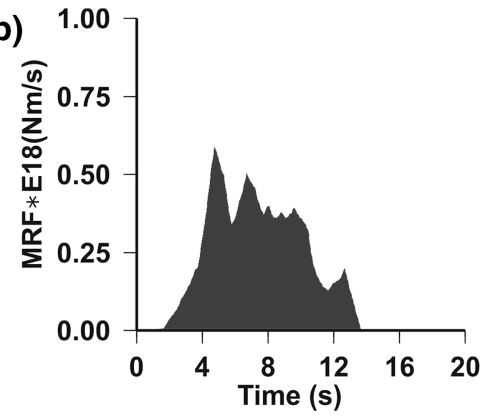

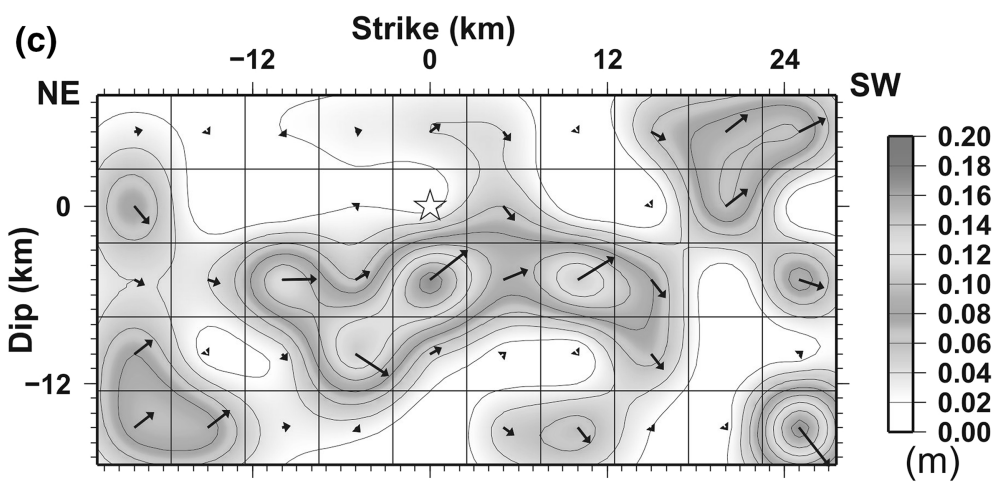

Fig. 4 Mechanism and slip distribution of the 10 June 2012 Fethiye $M w 6.1$ earthquake: a focal mechanism (reported by HRV), b MRF Moment Rate Function, c slip distribution on the fault plane. Vectors indicate the direction of motion. Star indicates hypocenter of the earthquake

source area was approximately $24 \mathrm{~km}$ long by $12 \mathrm{~km}$ wide. The duration of rupture was about $12 \mathrm{~s} \mathrm{(Fig.} \mathrm{4b).} \mathrm{The} \mathrm{main} \mathrm{rupture} \mathrm{is} \mathrm{located} \mathrm{around} \mathrm{the} \mathrm{initial} \mathrm{break} \mathrm{point} \mathrm{and} \mathrm{the}$ maximum slip is $0.2 \mathrm{~m}$ if shear modulus is assumed to be $30 \mathrm{GPa}$ (Fig. 4c). In the total slip 

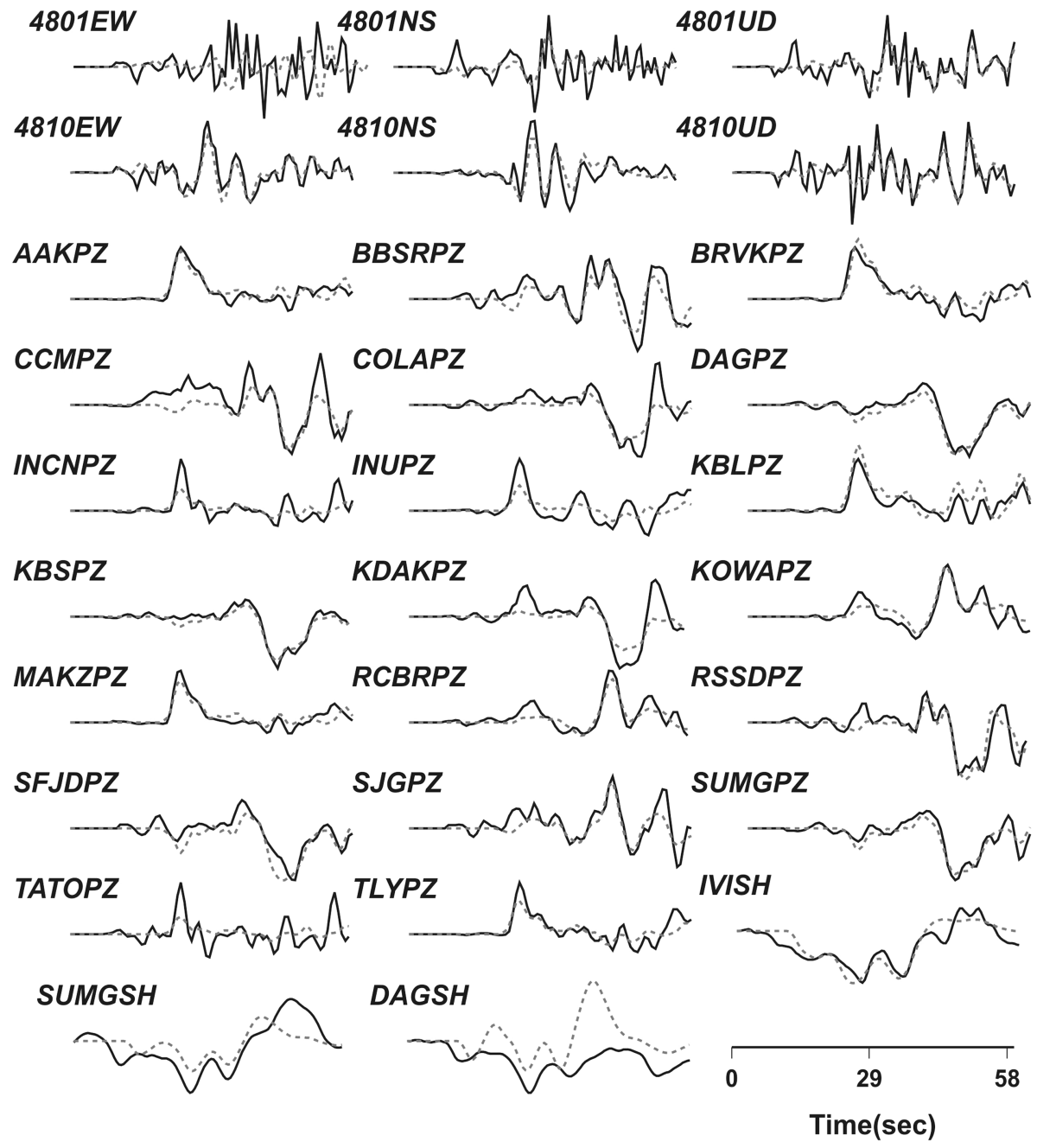

Fig. 5 Waveform fitting for joint inversion. 4801 and 4810 are strong ground motion records (NS NorthSouth, EW East-West and $U D$ Vertical Component), others are teleseismic records (PZ: Vertical P and $\mathrm{SH}: \mathrm{SH}$ waves)

distribution, a large asperity area can be seen in $2-3 \mathrm{~km}$ beneath the hypocentral area of the fault plane. The rupture is complex and gradually propagates from the hypocenter to southwest. The areas of maximum moment release are located beneath the hypocenter and about 15-20 km southwest of the hypocenter. The moment release and displacement rates in the shallower parts of the fault plane are smaller than in the deeper parts of the fault plane. Depth distributions of the study area earthquakes were also defined (Fig. 7b).

The north dipping fault plane was assumed to be the main plane in the focal mechanism for defining the faulting mechanism in the study area. The north dipping main active faulting in the northeast of Fethiye Gulf on shore served as a model for this assumption. Additionally, as it is derivable from Fig. 1a, the faults in the region gained the left lateral 


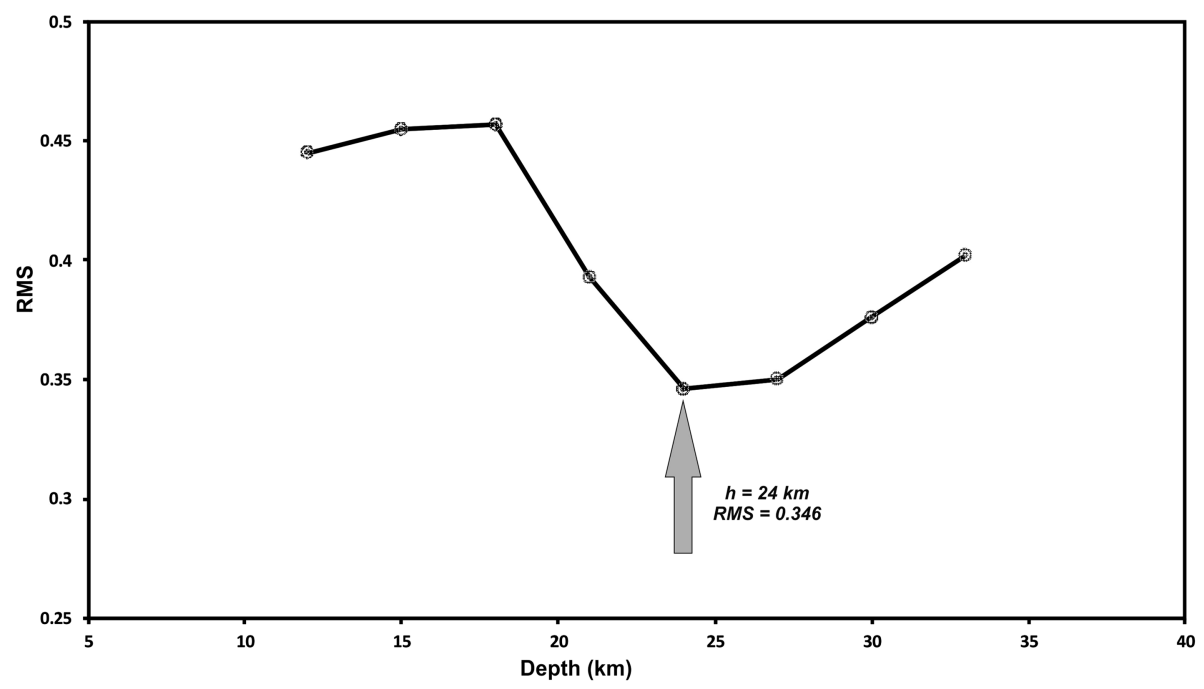

Fig. 6 Source depth versus RMS graph. As depth of the earthquake we selected a value that coincides with a minimum RMS value after computations

component when the extension created by the subduction was accompanied by an anticlockwise rotation of the plate including of Fethiye Gulf. This faulting style was effective in selecting the rupture plane for the main shock focal mechanism. Besides, in the inversion analysis the fault plane with NE-SW strike yielded a smaller Root Mean Square (RMS) error compared to the RMS error of the other fault plane.

\subsection{Kinematic and present-day stress analysis}

The principal stresses occurring during a fault plane rupturing or movement of blocks on a slip plane, and stress ratio are referred to as $\sigma_{1}$ (maximum compression), $\sigma_{2}$ (intermediate stress), and $\sigma_{3}$ (maximum tension) and $R$ respectively (Delvaux et al. 1997; Yamaji 2000; Angelier 2002). Kinematic features of the 10th June 2012 Fethiye earthquake source are determined by using focal mechanisms obtained from the source parameters of 29 selected earthquakes. 15 out of 29 earthquakes came from the data set- $A$ zone and the rest of the earthquakes came from the data set- $B$ and set- $C$ zones (Table 2). Along the 10 June 2012 Fethiye $M w 6.1$ main shock and aftershocks (data set-A zone), earthquakes (data set-B, C) of two different regions that are close to the data set-A zone were selected for the stress analysis to analyze the active faulting. Thus, including the past earthquakes occurred before the 10 June 2012 Fethiye $M w 6.1$ earthquake in the data set-B and set-C zones could help understanding the seismotectonic crust model better for the region. The stress analysis of the region was performed by using the $P$ - and $T$-axes obtained from the focal mechanism solutions of the earthquakes by the WIN TENSOR software (Delvaux and Sperner 2003). Types of the fault planes on which the 10 June 2012 earthquake and nearby earthquakes occurred and the origin of deformation were determined on the basis of the positions of the principal compression axis-pressure $\left(\sigma_{1}, \mathrm{P}\right)$ and principal tensional axis-tension $\left(\sigma_{3}, \mathrm{~T}\right)$ (Table 3 ). We constituted five earthquake data set zones from " $A$ " to " $E$ " to define the regional stress distribution and to find a relationship among the active faults around Rhodes 


\section{(a)}

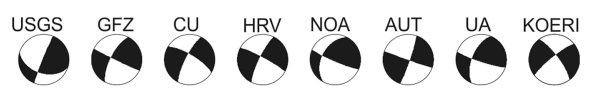

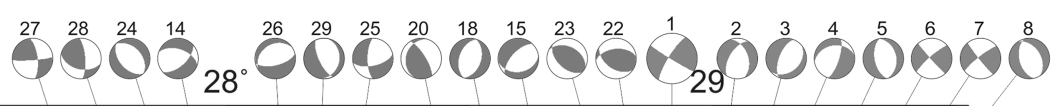

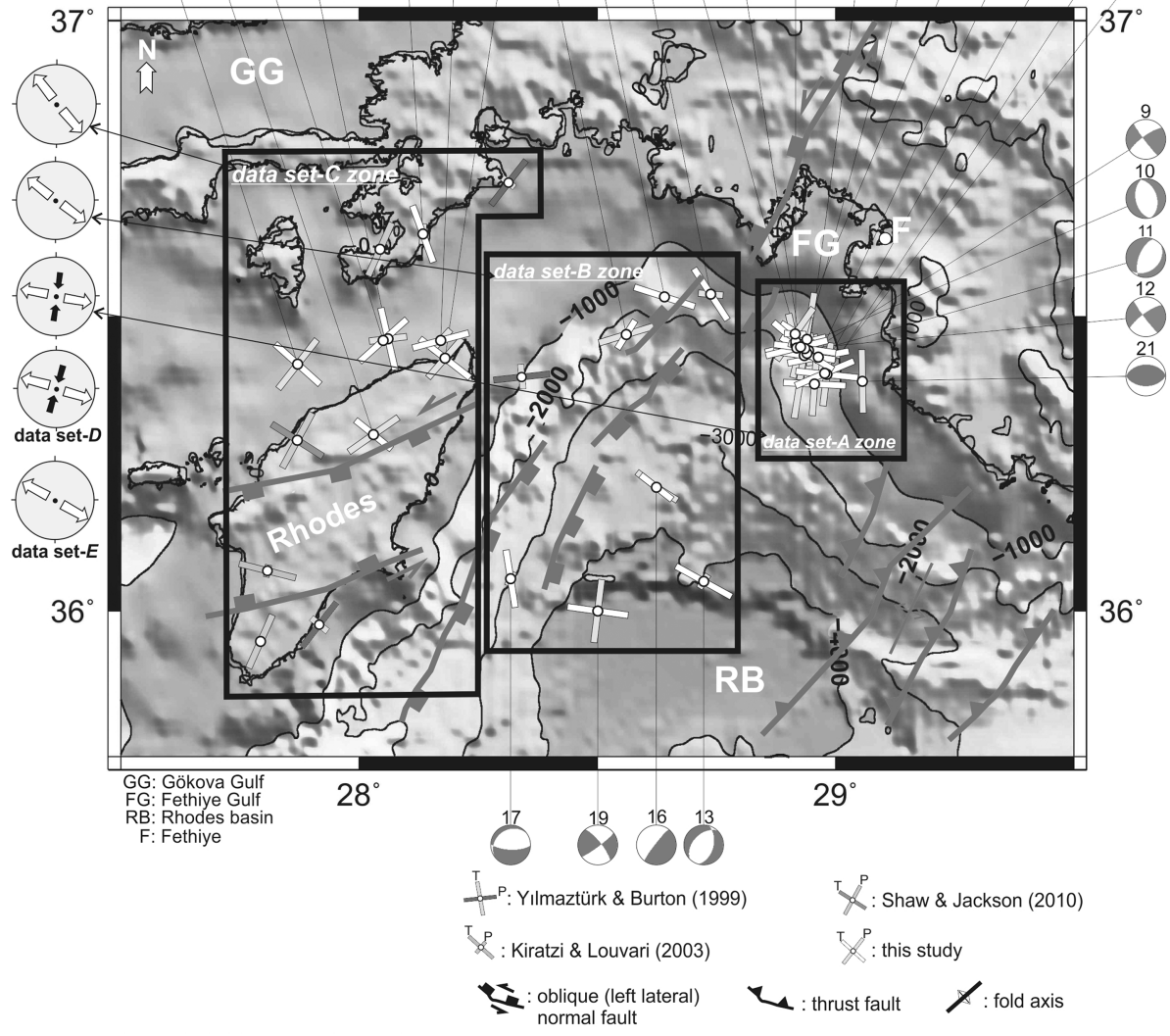

(b)
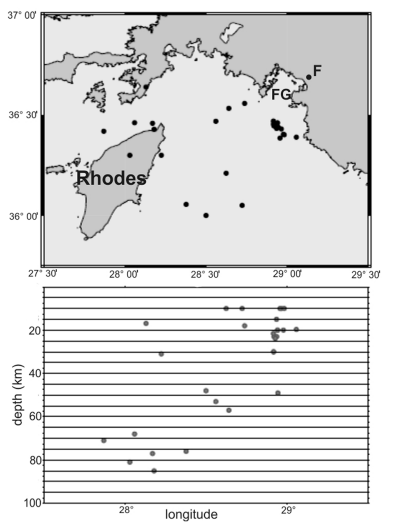

Island and the FBFZ located in the northeast of Fethiye Gulf shown in Fig. 1a. The data set- $A$ zone, contains the main shock of Fethiye $M w 6.1$ earthquake, numbered 1 along with its aftershocks numbered from 2 to 12 and the earthquakes that occurred before Fethiye 
Fig. 7 a Focal mechanism solutions according to the international seismological centers. Besides the focal mechanism solutions of the 10 June 2012 Fethiye $M w 6.1$ earthquake main shock and after shocks, bathymetry and active faults are shown (thrust and fold axes from Hall et al. 2009, faults located in Rhodes Island are adapted from Leite and Mascle 1982; Mascle and Martin 1990; normal faults between Rhodes Island and Fethiye Gulf are adapted based on the results of this study and from Hall et al. 2014). The focal mechanism solutions for the earthquakes $(\mathrm{M} \geq 3.5)$ and others are plotted with blue and red beach balls respectively. Closed polygons indicate the data set zones explained in the text. Distribution of the stress fields obtained from the focal mechanism solutions are shown by arrows (maximum principal compressional stress axis $\left(\sigma_{1}\right)$ and tensional stress axis $\left(\sigma_{3}\right)$ are shown with black and white arrows respectively) b Depth distribution of earthquakes in the study area

$M w 6.1$ earthquake, numbered 21, 22 and 23. The data set- $B$ zone includes the earthquakes that located in the northeast and east of Rhodes Island, and the data set- $C$ zone includes the earthquakes located in the northwest of Rhodes Island. Additionally, we developed the data set- $D$ by merging the data sets- $A$, and $-B$, and the data set- $E$ by merging the data sets $A$, $B$ and $C$ in Fig. 7 to analyze the occurrence of the 10th June 2012 Fethiye $M w 6.1$ earthquake better. The positions of $P$ - and $T$-axes were defined from the focal mechanism solutions of the 29 selected earthquakes including the main shock and aftershocks of Fethiye earthquake (see Fig. 7). The focal mechanism solutions of the earthquakes that occurred in the data set zones were evaluated with the WIN TENSOR software and rose diagrams prepared by the plunges of $P$ - and $T$-axes. In this way, the positions of the principal stress axes were defined for each zone and the whole region (Fig. 8).

The stress field obtained through focal mechanism solutions of 15 earthquakes in the data set- $A$ zone yielded $\left(\sigma_{1}\right)$ : sub-horizontal, $\left(\sigma_{2}\right)$ : sub-vertical and $\left(\sigma_{3}\right)$ : sub-horizontal (Fig. 8a). Evaluations of focal mechanisms of 14 earthquakes in the data set- $B$, and $C$ zones resulted in $\left(\sigma_{1}\right)$ and $\left(\sigma_{2}\right)$ : sub-vertical, $\left(\sigma_{3}\right)$ : horizontal (Fig. 8b, c). The stress field obtained from the focal mechanism solutions of 22 earthquakes in the data set$D$ zone resulted in $\left(\sigma_{1}\right)$ : sub-vertical, $\left(\sigma_{2}\right)$ : vertical and $\left(\sigma_{3}\right)$ : sub-horizontal (Fig. 8 d). The stress field for the data set- $E$ zone including 29 earthquakes yielded $\left(\sigma_{1}\right)$ and $\left(\sigma_{2}\right)$ : subvertical, and $\left(\sigma_{3}\right)$ : horizontal (Fig. 8e). The most prominent result of the stress tensor analyses carried out for each zone is that the $\sigma_{3}$ vector is more dominant than the $\sigma_{1}$ vector. Extension is dominant in the faulting of the zones including the main shock of Fethiye $M w 6.1$ earthquake, and other earthquakes. Additionally, strike-slip faulting accompanies the extension. This outcome is supported by the stress state in Table 3. The distributions of $P$ - and $T$-axes were displayed on both pole point $(\Omega)$ and contour diagram spheres by using the $P-T$ dihedra method proposed by Angelier and Mechler (1977) to detail the kinematic analyses in the five earthquake data set zones. The darkest areas in the contour diagrams are the best possible variation range for direction and angle values of the principal stress axes. The positions of the principal stress axes are compared with the dark areas on the contour diagrams, and the directional effect interval of each axis was defined for each zone. The directional effect intervals and strikes of $P$ and $T$-axes are compared with the rose diagrams (Fig. 9). It is understood from the contour diagrams of the study area that the minimum compressional stress $\left(\sigma_{3}\right)$ is closer to the ideal darkest areas and the primary stress tensor in the faulting of the region. The maximum principal compression stress $\left(\sigma_{1}\right)$ with the strikes of $P$-axes, and the maximum principal extension stress $\left(\sigma_{3}\right)$ with the strikes of $T$-axes were compared for each dataset zone. As a result, it was found out that all of the principal stress axes change in a certain direction range (Table 4). 


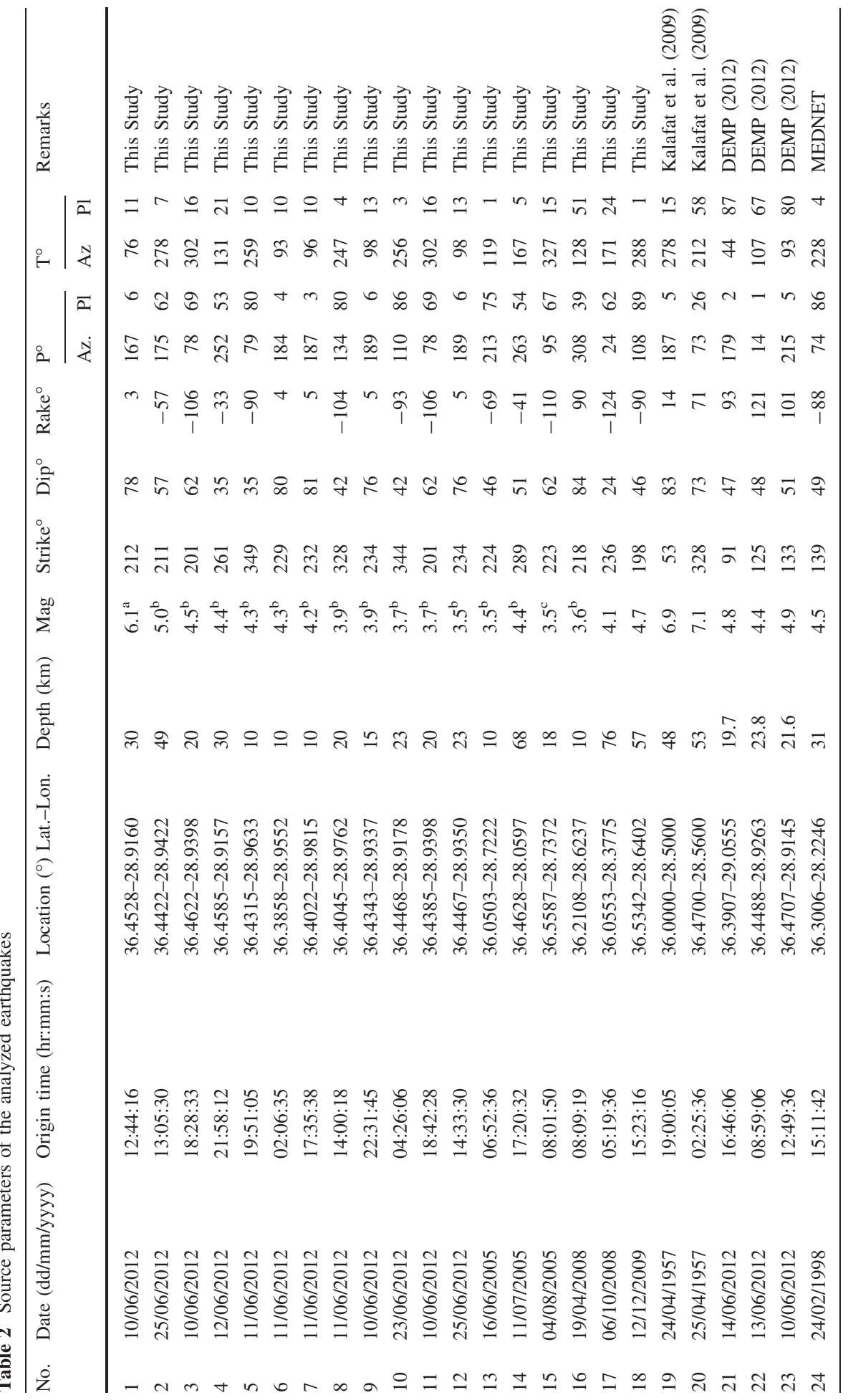




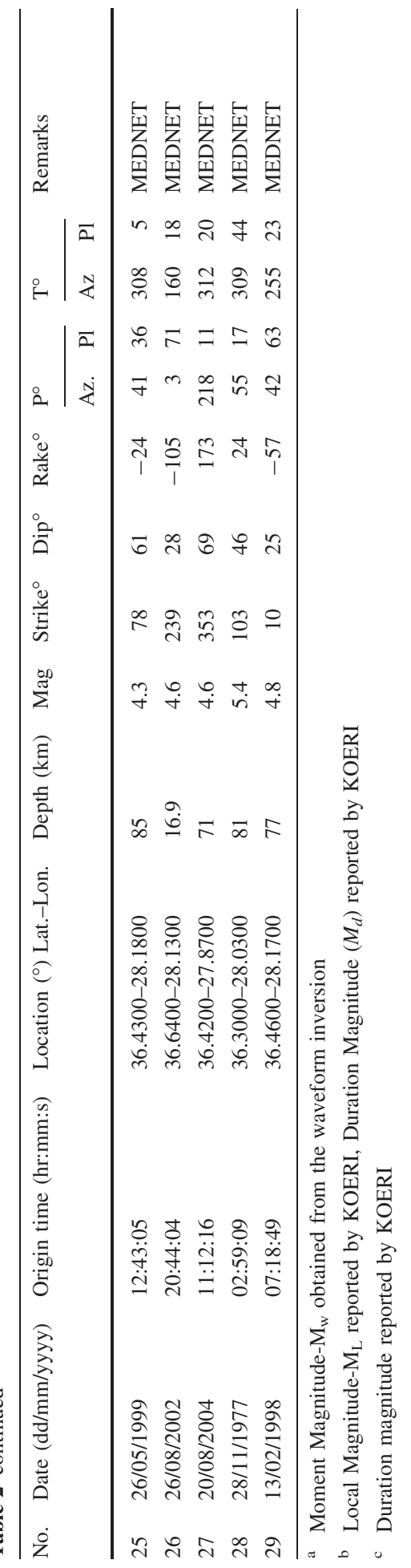


Table 3 Stress tensor results obtained from the focal mechanism solutions of the 29 earthquakes for each data zone

\begin{tabular}{|c|c|c|c|c|c|c|}
\hline $\begin{array}{l}\text { Focal mechanisms } \\
\text { of data set no }\end{array}$ & $\begin{array}{l}\sigma_{1} \\
\left(\mathrm{Az}^{\circ} /\right. \\
\left.\mathrm{Pl}^{\circ}\right)\end{array}$ & $\begin{array}{l}\sigma_{2} \\
(\mathrm{Az} \% \\
\left.\mathrm{Pl}^{\circ}\right)\end{array}$ & $\begin{array}{l}\sigma_{3} \\
\left(\mathrm{Az}^{\circ} /\right. \\
\left.\mathrm{Pl}^{\circ}\right)\end{array}$ & $\begin{array}{l}\text { Stress } \\
\text { ratio }(\mathrm{R})\end{array}$ & $\begin{array}{l}\text { Average misfit } \\
\text { angle }(\beta)\end{array}$ & Stress state \\
\hline Data set- $A$ & $09 / 14$ & $232 / 71$ & $102 / 12$ & 0.96 & 25.67 & $\begin{array}{l}\text { Extensional strike-slip } \\
\text { (NW-SE) }\end{array}$ \\
\hline Data set- $B$ & $31 / 49$ & $224 / 40$ & $128 / 07$ & 0.46 & 40.32 & $\begin{array}{l}\text { Oblique extensional } \\
\text { (NW-SE) }\end{array}$ \\
\hline Data set- $C$ & $54 / 52$ & $229 / 30$ & $321 / 02$ & 0.48 & 24.71 & $\begin{array}{l}\text { Pure extensional } \\
\quad(\mathrm{NW}-\mathrm{SE})\end{array}$ \\
\hline Data set- $D$ & $15 / 21$ & $222 / 67$ & $109 / 10$ & 0.85 & 36.73 & $\begin{array}{l}\text { Extensional strike-slip } \\
\text { (NW-SE) }\end{array}$ \\
\hline Data set- $E$ & $14 / 42$ & $222 / 44$ & $118 / 14$ & 0.85 & 40.20 & $\begin{array}{l}\text { Oblique extensional } \\
\text { (NW-SE) }\end{array}$ \\
\hline
\end{tabular}

$\sigma_{1}, \sigma_{2}$ and $\sigma_{3}$ are maximum, intermediate and minimum principal stress axes respectively and stress ratio is $(\mathrm{R})=\left(\sigma_{2}-\sigma_{3}\right) /\left(\sigma_{1}-\sigma_{3}\right)$

The average misfit angle, one of the parameters in the stress tensor analysis of the faults in a region, was computed for each data set zone in the study area (see Table 3). The uniformity of slickensides is evaluated by the misfit angle which is one of the stress analysis components. Micheal (1991) estimated a $34^{\circ}$ misfit angle in an area where slickensides were homogenous and stated that the variations in the misfit angles cause differentiation in stress state. The misfit angles of the data set- $A$ and data set- $C$ zones are approximately equal, but the misfit angle of the data set- $B$ is larger compared to the other two data set zones. The variation in the misfit angle may be supportive evidence for the extension accompanied with a strike-slip faulting. The focal mechanism solutions carried out by the different international seismological centers for the main shock of Fethiye $M w$ 6.1 earthquake support the extensional and strike-slip faulting defined in Table 3.

\section{Discussions}

Previous researchers suggested different approaches to the seismotectonic regime in Rhodes Island and vicinity, in a corridor among Rhodes Island and Fethiye Gulf and north of Fethiye Gulf. The dominant active stress was indicated to be NW-SE extension accompanied by a left lateral stress based on the focal mechanism solutions in Rhodes Island and vicinity (Kiratzi and Louvari 2003; Chamot-Rooke et al. 2005; Shaw and Jackson 2010). Almost all authors remarked a dominant NW-SE extension according to the focal mechanism solutions, slickensides and slickenlines in the Holocene units in the FBFZ (Y1lmaztürk and Burton 1999; Ten Veen and Kleinspehn 2003; Kreemer and ChamotRooke 2004; Verhaert et al. 2006; Alçiçek et al. 2006; Över et al. 2010). The focal mechanism solution of the 12 May $1971 M 6.2$ earthquake that occurred in the FBFZ yielded normal faulting and NW-SE T- axis (Y1lmaztürk and Burton 1999). One of the two earthquakes $(M \geq 5)$ that located in the south of Fethiye Gulf on 12 May 1971 presented a strike slip focal mechanism with an extension component, but the other earthquake that occurred at the same location and date indicated a thrust type focal mechanism. Both earthquakes had NW-SE T-axis (Ebeling et al. 2012). Some studies explained the origin of 
the extension as being related to the forearc development (Mascle and Martin 1990; Ten Veen and Kleinspehn 2003). On the other hand, the Esençay basin located in the southeast of Fethiye Gulf and the edge of the west limb of the Isparta angle was defined as forearc (Ten Veen 2004). Hall et al. (2009) mapped the FBFZ left lateral strike slip fault with thrust component. The distribution of the stress states in the northeast of Fethiye Gulf varies with geologic age. The region was dominated by a NW-SE pure compression that originated by the Isparta Angle in the Lower Miocene and a NW-SE extension that followed after the crust thickening due to compression from the Pliocene to Recent (Över et al. 2012). The NE-SW normal faults seen in the NW-SE seismic reflection sections between Rhodes Island and Fethiye Gulf have been formed by the sinistral Pliny Strabo Fault Zone (PSFZ) (Hall et al. 2014).

The influence zone (data set- $A$ ) of the 10 June 2012 Fethiye $M w 6.1$ earthquake and the origin of the active faults that created the stress field in the neighboring areas of Fethiye earthquake could be explained in two ways based on the dominant extension accompanied partially strike-slip component obtained from the focal mechanism solutions. The first possible explanation is the existence of grifted normal faults with compressional tectonic regime due to the Hellenic Arc and later normal faults that contributed to the forearc development. The second possible explanation is sinistral and transtensional faults caused by the subduction of the Hellenic Arc. To test these two opinions in this study, stress distributions analyzed in the three main data zones and the two other combined data zones were evaluated. The geometry of the northeastern extension of the Pliny and Strabo faults reaching to the FBFZ was determined. Additionally, an effort was made to define continuation of the secondary thrust faults associated with the Hellenic Arc and the west limb of the Isparta angle in the Mediterranean. The seismotectonic model of the region is displayed by a block diagram (Fig. 10a). The principal maximum compression is prominent in the NW-SE direction according to the strain distributions obtained from the GPS data shown in Fig. 1b, c for the study area and vicinity. This situation is a result of the anticlockwise rotational movement of the region between the east and southeast of Fethiye Gulf (Kissel and Poisson 1986). Hall et al. (2009) mapped the active faults as NE-SW thrust and sinistral strike slip, displayed in Fig. 1a, using the seismic reflection method in a region from approximately $20 \mathrm{~km}$ of southeast data set- $A$ zone and $40 \mathrm{~km}$ east and southeast of Rhodes Island. The extension effects in the E-W direction according to the focal mechanism solutions of the earthquakes are generated by the N-S trending normal faults displayed in Fig. 1a between Crete and Rhodes Island located in the west limb of the Hellenic-Cyprus Arc (Armijo et al. 1992; Kreemer and Chamot-Rooke 2004). Shaw and Jackson (2010) defined normal faulting due to extensional stress from the focal mechanism solutions of some earthquakes in a zone between the south of Rhodes Island and the Hellenic Arc. The direction of extension mentioned in the previous studies is considered to comply with the WNW-ESE extension obtained from the data set- $A$ and set- $D$ zones. The extension in the data set- $C$ zone is mainly NW-SE and pure. The stress parameters obtained from the data set- $E$ zone indicate that the upper crust is deformed by the active faults for which extension component is dominant over sinistral component. As is understood from Figs. 7 and 8, the maximum tensional-minimum compression stress axis $\left(\sigma_{3}\right)$ vector is prominent in the whole region. This extension indicates that the normal faults generate the majority of the earthquakes, and sinistral strike slip accompanies normal faulting due to the rotation around Fethiye Gulf. This explains why the transtensional stresses (i.e. those related to strike slip faulting) and extensional stresses are grift in the region. The stress field of the data set- $B$ zone shows that the earthquakes mainly occur on the planes of normal faults in this zone (see Fig. 8b). These normal faults are similar to the faults located 
(a) left panel data set- $A$ zone right panel

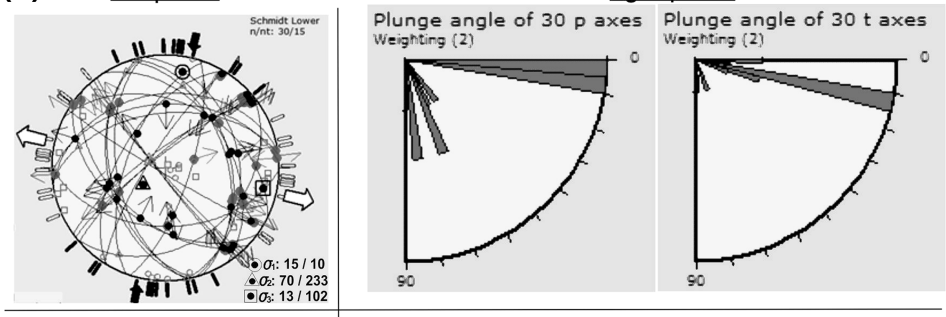

(b)

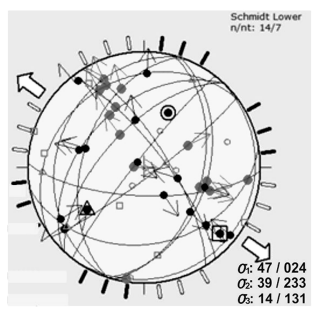

data set- $B$ zone

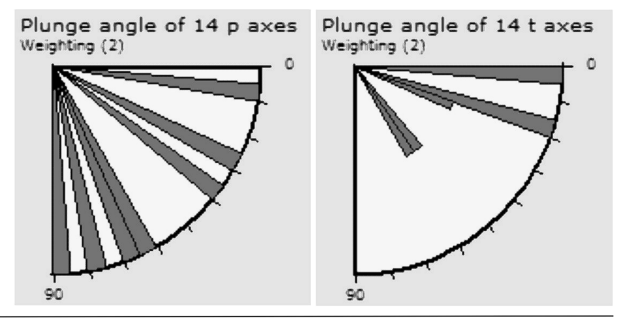

(c)

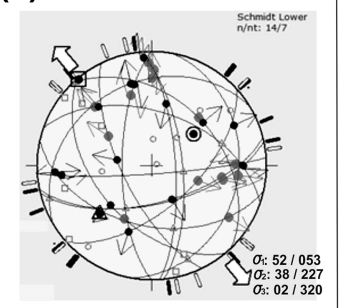

data set- $C$ zone

Plunge angle of $14 p$ axes Plunge angle of $14 t$ axes Weighting (2)

(d)
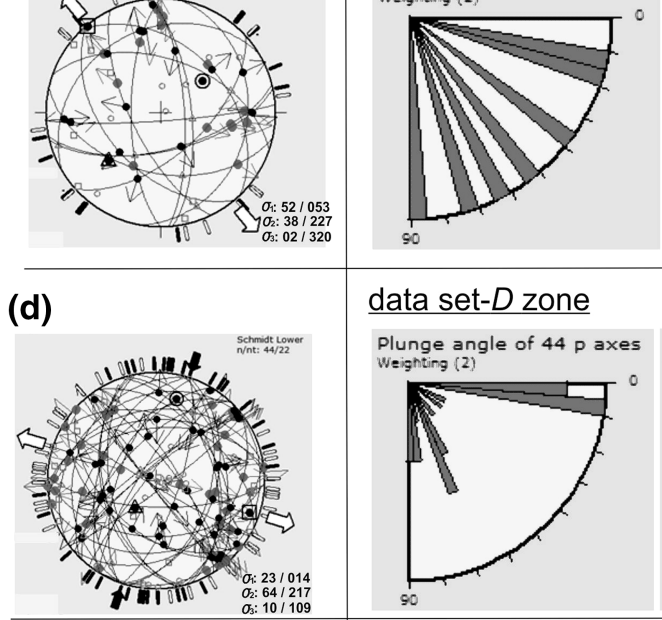
Weighting (2)

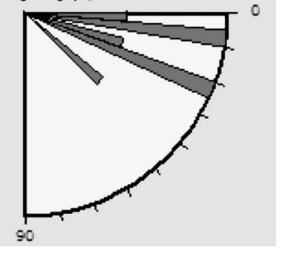

\section{data set- $D$ zone}

Plunge angle of $44 p$ axes Plunge angle of $44 t$ axes Weighting (2)

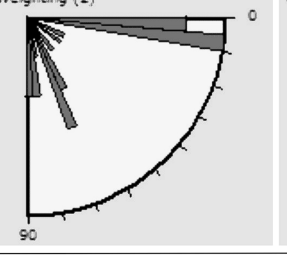
Weighting (2)

(e)

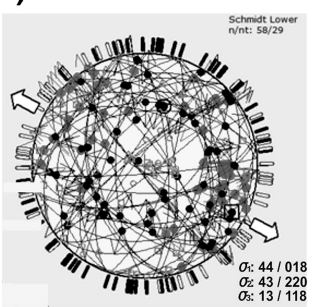

\section{data set- $E$ zone}

Plunge angle of $58 \mathrm{p}$ axes Weighting (2)

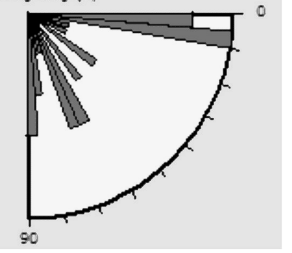

Plunge angle of $58 \mathrm{t}$ axes Weighting (2)

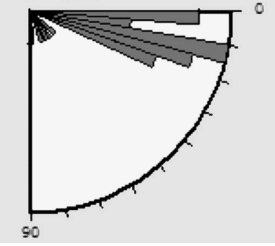


4Fig. 8 Positions of the principal stress axes obtained from focal mechanism solutions of the earthquakes in the a data set- $A$, b data set- $B$, c data set- $C$, d data set- $D$, e data set- $E$ zones in the lower hemisphere (left panel), distributions of $P$ - and $T$-axes (right panel) based on plunge values on the rose diagrams

on the edge of the forearc basin (RB) that developed following the thrust faulting. In other words, the WNW-ESE oriented extension indicates that the FBFZ continues to the northwestern edge of the Rhodes Basin as oblique (left lateral) normal faults in segment. This evidence supports Kreemer and Chamot-Rooke (2004) (see Fig. 7). Besides, the dominant strike direction of $T$-axes is NW-SE (see Fig. 9).

The orientation of the principal stress axis $\left(\sigma_{3}\right)$ of the stress field created by the earthquakes in the data set- $B$ and data set- $D$ zones supports the NW-SE dominant extension. The NE-SW normal faults border the Aksu Basin and the Antalya Gulf located east and southeast of the study area and in the vicinity of the east limb of the Isparta angle, which indicate the presence of extensional stress in this region. The Pliny and Strabo trenches located around the Hellenic Arc are defined as transtensional areas of NE-SW sinistral strike-slip faulting (Huguen et al. 2001).

The downthrown NNE-SSW trending normal faults that border the graben areas were defined along the vicinity areas of Rhodes Island's southeast coastline in north of the Hellenic Arc (Lekkas et al. 2000; Titschack et al. 2013). The NW-SE trending extension in the data set- $C$ zone supports this hypothesis (see Fig. 8). Additionally, normal faults that developed parallel to NE-SW reverse faults were mapped in Catalan Coastal Ranges of Valencia-Spain located in the NW of the Mediterranean Sea (Baqués et al. 2009). This structural pattern is similar to the fault geometries in the study area. The main shock and aftershocks of the 10 June 2012 Fethiye $M w 6.1$ earthquake occurred in a strike-slip dominant tectonic setting (Görgün et al. 2014).

The origin of the deformation may be associated with the development of the Hellenic Arc based on the tensional or compressional strike slip faulting obtained from the focal mechanism solutions of the 10 June 2012 Fethiye $M w 6.1$ earthquake by the international seismology centers. This postulation is supported by the slip vectors of two different events observed on the slip plane of Fethiye $M w 6.1$ earthquake. Hall et al. (2009) indicated that dominant compression around the southeast of the region could create small scale intraplate strike-slip faults. Additionally, the explicit strike-slip offset in the focal mechanism solutions of the Fethiye $M w 6.1$ earthquake and its aftershocks may be developed by the rotational movement of the region (see Fig. 7). It is possible to explain the faults that produce earthquakes in the study area by using the compressional arc seismotectonic model, one of the forearc evolution models (Fig. 10a). When the region between Rhodes Island and Fethiye Gulf is evaluated, several active faults which caused forearc development (related to the Hellenic arc) can be explained by an extension after compression was noticeable. The continuation of the NW-SE compression until today in the east and southeast of the study area has led to a forearc origin bathymetry (the Rhodes Basin). The NE-SW trending normal faulting mechanism which is the indication of the extensional deformation, was created by the effect of compression in the deep section of the western Mediterranean crust (Fig. 10b). Busby (2004) defined a similar tectonic evolution for the Baja California, Mexico. Another similar forearc tectonic model, considered for the Rhodes Basin in this study, is the development of the Plio-Quaternary Ionian forearc basins associated with the subduction in the Ionian Sea south of Italy (Cavazza and Barone 2010).

The dominance of $\left(\mathrm{T}, \sigma_{3}\right)$ to $\left(\mathrm{P}, \sigma_{1}\right)$ determined by this study in the region could be explained by not only a transtensional regime due to the sinistral strike slip faulting in the 

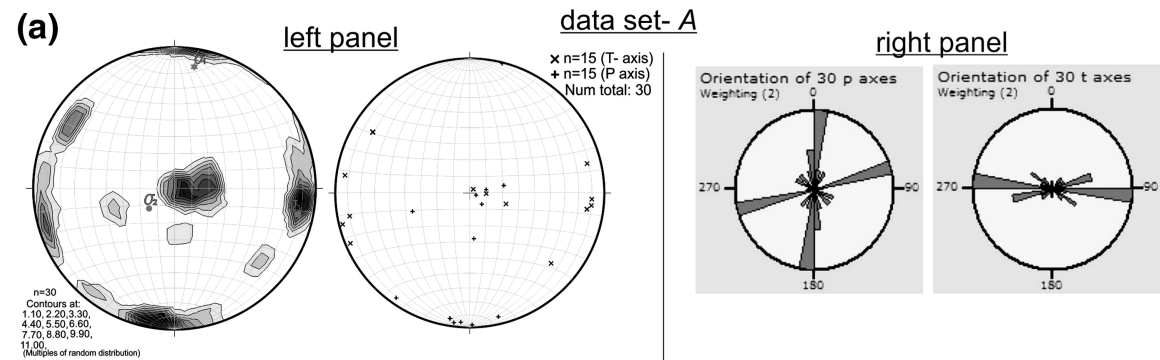

(b)

data set- $B$
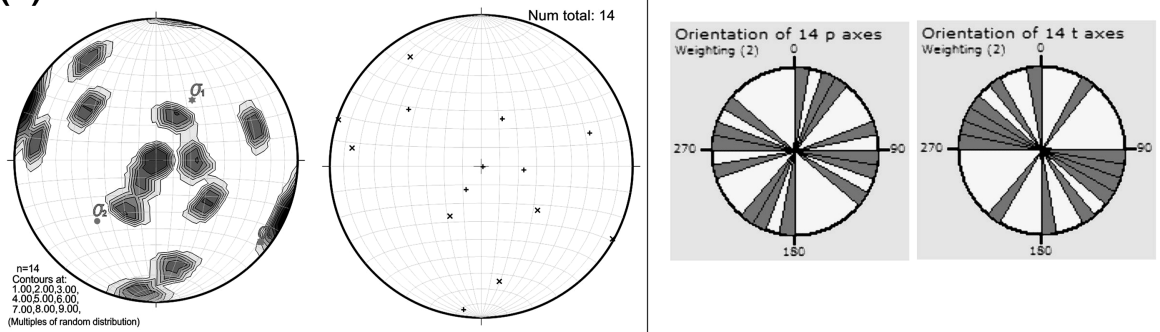

(c)
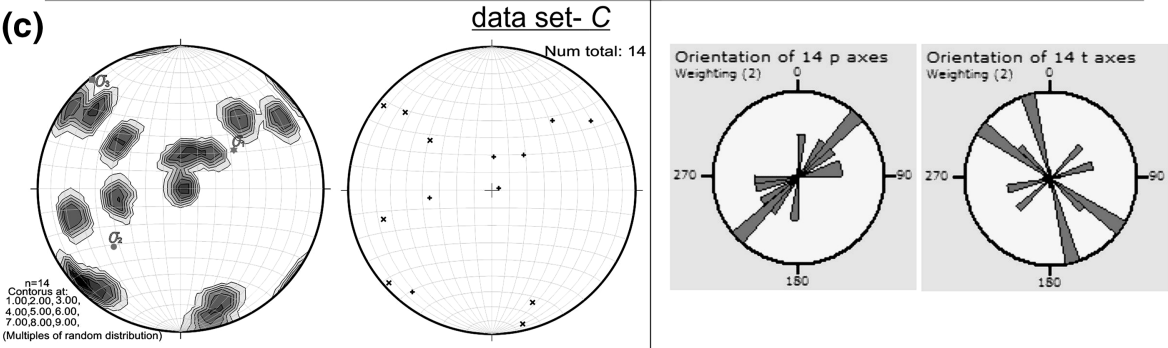

(d)
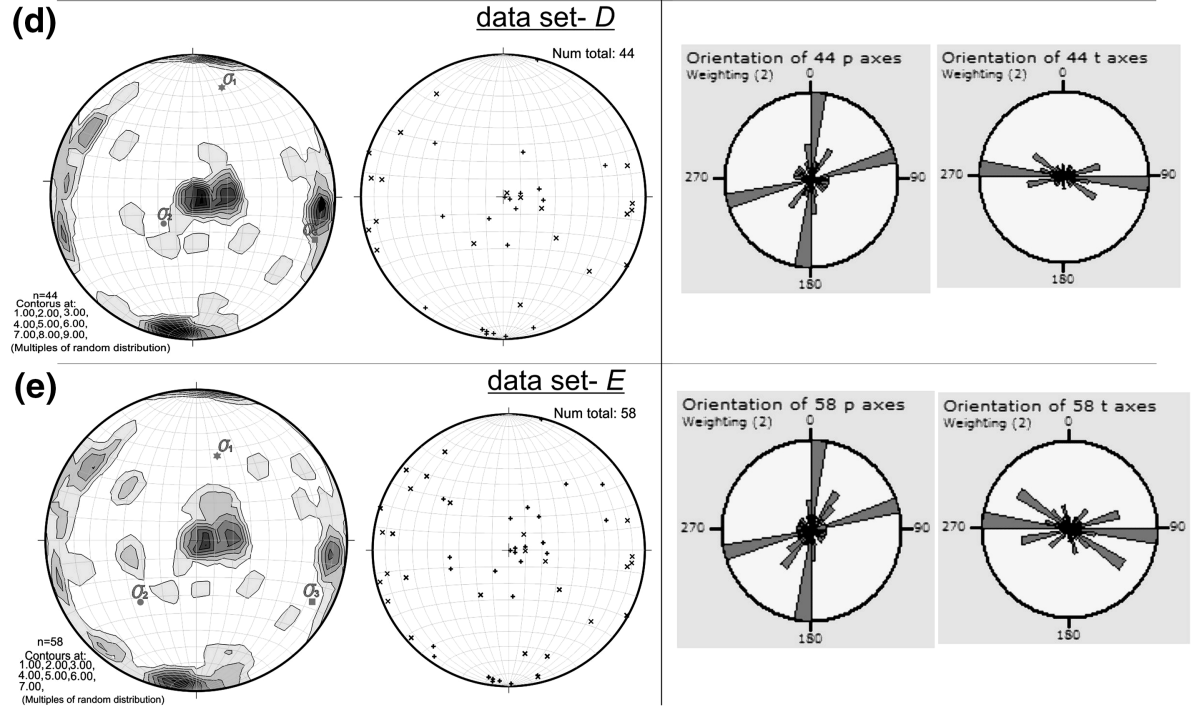
4 Fig. 9 Contour, point of pole $(\Omega)$ (left panel) and rose diagrams according to strike of the P- and $\mathrm{T}$ axes (right panel) obtained from the focal mechanism solutions of the earthquakes in the a data set- $A$, b data set$B$, c data set- $C$, d data set- $D$, e data set- $E$ zones shown from left to right (equal area lower hemisphere are used for the contour and $(\Omega)$ diagrams)

Table 4 The variation range of the compression $\left(\sigma_{1}\right)$ and extension $\left(\sigma_{3}\right)$ directions created by the $P$ - and $T$ axes obtained through the focal mechanisms of the study area earthquakes in Fig. 9 right panel

\begin{tabular}{|c|c|c|c|c|c|}
\hline \multirow[t]{2}{*}{ Data set no. } & \multirow[t]{2}{*}{ Earthquake no. } & \multicolumn{2}{|c|}{ Focal mechanisms } & \multicolumn{2}{|c|}{ Orientation, Strike } \\
\hline & & $\mathrm{P}^{\circ}$ axes & $\mathrm{T}^{\circ}$ axes & $\mathrm{P}^{\circ}$ axes, $\sigma_{1}$ & $\mathrm{~T}^{\circ}$ axes, $\sigma_{3}$ \\
\hline \multirow[t]{15}{*}{ Data set- $A$} & 1 & 167 & 76 & N5-25E & N65-85W \\
\hline & 2 & 175 & 278 & & \\
\hline & 3 & 78 & 69 & & \\
\hline & 4 & 252 & 131 & & \\
\hline & 5 & 79 & 259 & & \\
\hline & 6 & 184 & 93 & & \\
\hline & 7 & 187 & 96 & & \\
\hline & 8 & 134 & 247 & & \\
\hline & 9 & 189 & 98 & & \\
\hline & 10 & 110 & 256 & & \\
\hline & 11 & 78 & 302 & & \\
\hline & 12 & 189 & 98 & & \\
\hline & 21 & 179 & 44 & & \\
\hline & 22 & 121 & 107 & & \\
\hline & 23 & 215 & 93 & & \\
\hline \multirow[t]{7}{*}{ Data set- $B$} & 13 & 213 & 119 & N5-35E & N55-85W \\
\hline & 15 & 95 & 327 & & \\
\hline & 16 & 308 & 128 & & \\
\hline & 17 & 24 & 171 & & \\
\hline & 18 & 108 & 288 & & \\
\hline & 19 & 187 & 278 & & \\
\hline & 20 & 73 & 212 & & \\
\hline \multirow[t]{7}{*}{ Data set- $C$} & 14 & 263 & 167 & N40-80E & N10-40W \\
\hline & 24 & 74 & 228 & & \\
\hline & 25 & 41 & 308 & & \\
\hline & 26 & 3 & 160 & & \\
\hline & 27 & 218 & 312 & & \\
\hline & 28 & 55 & 309 & & \\
\hline & 29 & 42 & 255 & & \\
\hline Data set- $D$ & & & & N10-80E & N30-80W \\
\hline Data set- $E$ & & & & N30-80E & N50-60W \\
\hline
\end{tabular}

FBFZ but also an extensional regime due to compression. A dense seismic network with broad band seismometers and seismic reflection could be used to resolve which tectonic origin is dominant in the region. 


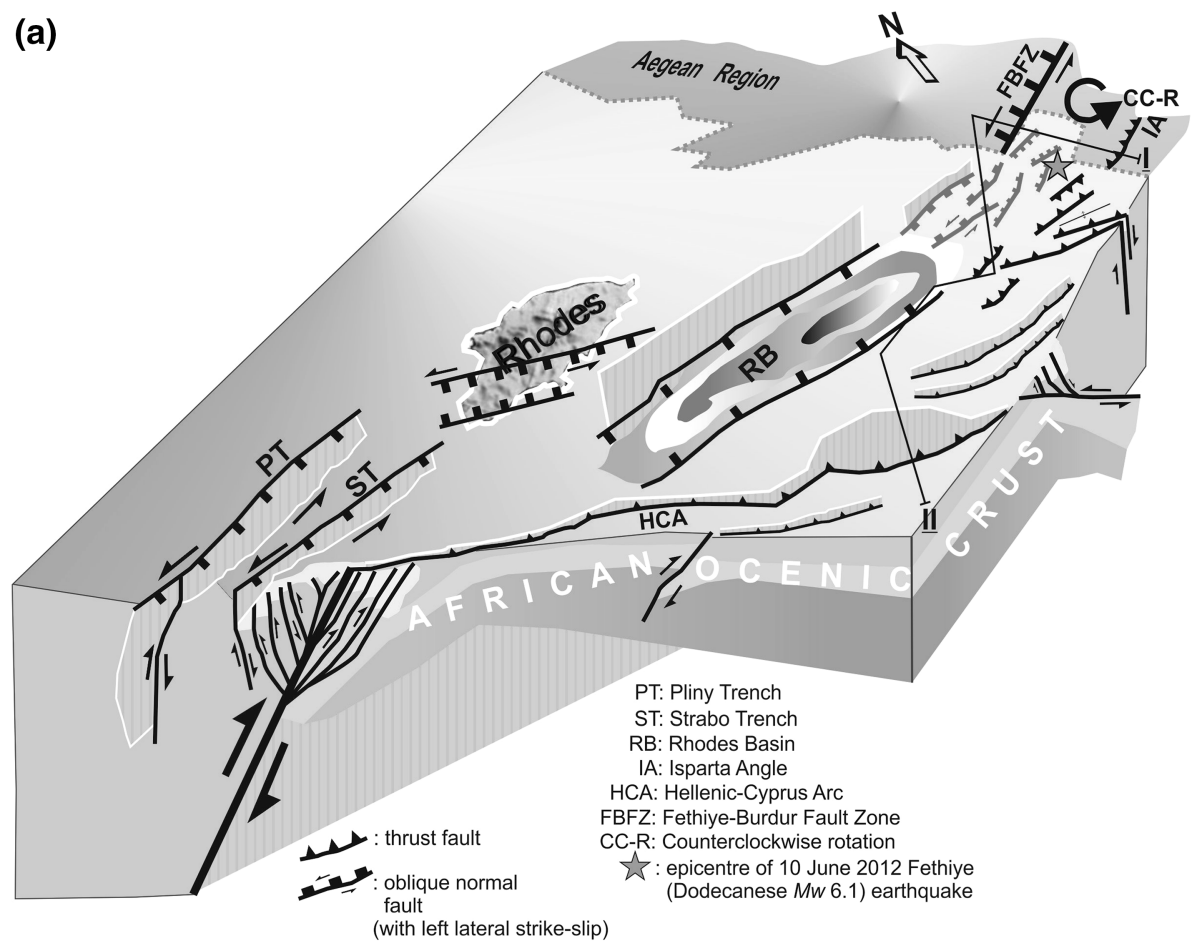

(b)

\section{Compressional Arc}

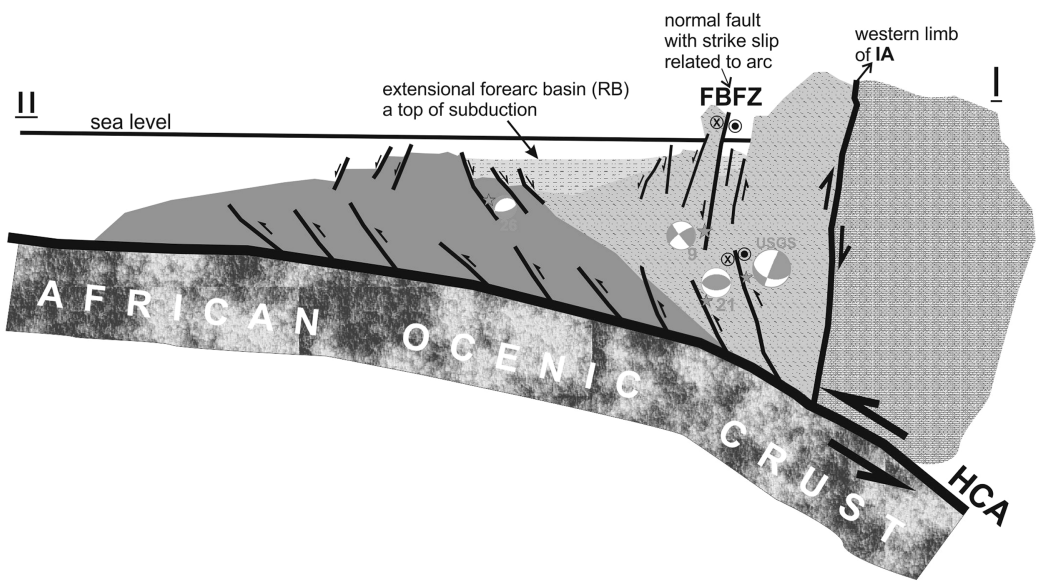

Fig. 10 a Block diagram of the seismotectonic model of the region b I-II cross section (not to scale and modified from Busby 2004) displaying the hypocenters of the 10 June 2012 Fethiye $M w 6.1$ earthquake main shock and other earthquakes with different focal mechanisms associated with the faults marked in red 


\section{Conclusions}

The inverted source-rupture model of the 10 June 2012 Fethiye $M w 6.1$ earthquake indicated that the rupture process is complex and the faulting has a main asperity and two small asperities. The main asperity is located $2-3 \mathrm{~km}$ beneath the hypocenter with a maximum slip of about $0.2 \mathrm{~m}$. The rupture propagated to the southwest. The moment release and displacement rates in the shallower parts of the fault plane are smaller than in the deeper parts of the rupture plane. The effective source area is about $24 \mathrm{~km}$ long by $12 \mathrm{~km}$ width. An oblique faulting associated with a NW-SE extension component that is more dominant than the strike-slip component that was determined by the focal mechanism solutions of 10 June 2012 Fethiye $M w 6.1$ earthquake main shock and aftershocks included in the data set$A$ zone. The zone that includes Fethiye $M w 6.1$ earthquake is a transition zone between pure compression and extension, so earthquakes with all possible faulting types should be expected to occur in this zone. It is understood that the FBFZ extends farther southeast as a segment with normal faulting and the normal faults located at the edge of the Rhodes Basin are parts of this system.

The seismicity in the region can be explained by the NW-SE trending normal faults located in the shallow depths $(\leq 20 \mathrm{~km})$ of the crust and the thrust faults (related to the Hellenic Arc) in the deeper part $(\geq 20 \mathrm{~km})$ of the crust. The extension occurred after the compression in the southeast of Fethiye Gulf, contributed to forming of the NE-SW normal faults similar to the forearc basin boundary faults. The compression which developed the Hellenic Arc causes a movement to the southwest in the plate that contains the Fethiye Gulf. Since the curvature of the arc to the north causes an anticlockwise rotation in the Fethiye Gulf plate, the sinistral strike-slip component accompanies the stress distribution of the region. However, the vertical displacement is greater than the horizontal (sinistral) and creates oblique slip in the geometries of the faults that are capable of generating earthquakes.

Acknowledgments The authors would like to express their gratitude to two anonymous reviewers and the editor, Prof. Dr. Peter VARGA, for their constructive comments.

\section{References}

Akyol N, Zhu L, Mitchell BJ, Sözbilir H, Kekovalı K (2006) Crustal structure and local seismicity in Western Anatolia. Geophys J Int. doi:10.1111/j.1365-246X.2006.0353

Alçiçek MC, Ten Veen JH, Özkul M (2006) Neotectonic development of the Çameli Basin, southwestern Anatolia, Turkey. In: Robertson AHF, Mountrakis D (eds) Tectonic development of the eastern Mediterranean region. Geological Society of London, Special Publication 260, pp 591-611

Ambraseys NN (2009) Earthquakes in the Mediterranean and Middle East: a multidisciplinary study of seismicity up to 1900. Cambridge University Press, Cambridge. ISBN-13: 9780521872928

Angelier J (2002) Inversion of earthquake focal mechanisms to obtain the seismotectonic stress IV-a new method free of choice among nodal lines. Geophys J Int 150:568-609

Angelier J, Mechler P (1977) Sur une méthode graphique de recherche des contraintes principales également utilisable en tectonique et en séismologie: la méthode des di 'edres droits'. Bull. de la Société Géologique de France 7:1309-1318

Armijo R, Lyon-Caen H, Papanastassiou D (1992) E-W extension and Holocene normal fault scarps in the Hellenic Arc. Geology 20:491-494

Ayhan ME, Demir C, Lenk O, Kılıçoğlu A, Altıner Y, Barka AA, Ergintav S, Özener H (2002) Inter-seismic strain accumulation in the marmara sea region. Bull Seismol Soc Am 92:216-229 
Baqués V, Travé A, Benedicto A, Labaume P (2009) Relationship between fluid flow and tectonic brecciation in the Neogene extensional Vallès-Penedès basin (Catalan Ranges, NE Iberian). J Geochem Explor 101:4

Barka AA (1992) The North Anatolian Fault zone. Ann Tecton 6:164-195

Bozkurt E (2001) Neotectonics of Turkey—a synthesis. Geodyn Acta 14:3-30

Busby C (2004) Continental growth at convergent margins facing large ocean basins: a case study from Mesozoic convergent-margin basins of Baja California, Mexico. Tectonophysics 392:241-277

Cavazza W, Barone M (2010) Large-scale sedimentary recycling of tectonic mélange in a forearc setting: the Ionian basin (Oligocene-Quaternary, southern Italy). GSA Bulletin 122(11-12):1932-1949. doi:10. 1130/B30177.1

Chamot-Rooke N, Rabaute A, Kreemer C (2005) Western Mediterranean Ridge mud belt correlates with active shear strain at the prism-backstop geological contact. Geology 33(11):861-864. doi:10.1130/ G21469.1

Chaumillon E, Mascle J (1995) Variation latérate des fronts de déformation de la Ride Méditerraneénne (Méditerraneé orientale). Bull Soc Geol Fr 166:463-478

Clarke PJ, Davies RR, England PC, Parsons B, Billiris H, Paradissis D, Veis G, Cross PA, Denys H, Ashkenazi V, Bingley R, Kahle HG, Muller MV, Briole P (1998) Crustal strain in central Greece from repeated GPS measurements in the interval 1989-1997. Geophys J Int 135(1):195-214

Delvaux D, Sperner B (2003) New aspects of tectonic stress inversion with reference to the TENSOR program. In: Nieuwland DA (ed) New insights into structural interpretation and modelling. Geological Society Special Publications 212, London, pp 75-100

Delvaux D, Moeys R, Stapel G, Petit C, Levi K, Miroshnichenko A. Ruzhich V, Sankov V (1997) Paleostress reconstructions and geodynamics of the Baikal region, Central Asia. Part II: Cenozoic rifting. In: Cloetingh S, Fernandez M, Munoz JA, Sassi W, Horvath F (eds) Structural controls on sedimentary basin formation. Tectonophysics, vol 282, pp 1-38

Dewey JF, Pitman WC, Ryan WBF, Bonnin J (1973) Plate tectonics and the evolution of the Alpine system. Geol Soc Am Bull 84:3137-3180

Duermeijer CE, Nyst M, Meijer PT, Langereis CG, Spakman W (2000) Neogene evolution of the Aegean arc: palaeomagnetic and geodetic evidence for a rapid and young rotation phase. Earth Planet Sci Lett 176:509-525

Ebeling CW, Okal EA, Kalligeris N, Synolakis CE (2012) Modern seismological reassessment and tsunami simulation of historical Hellenic Arc earthquakes. Tectonophysics 530-531:225-239

EMSC (2012) European-Mediterranean Seismological Centre. http://www.emsc-csem.org/Earthquake/ mtfull.php?id=272709. Visited 26 July 2012

Ganas A, Parsons T (2009) Three-dimensional model of Hellenic Arc deformation and origin of the Cretan uplift. J Geophys Res 114:B06404. doi:10.1029/2008JB005599

Glover C, Robertson A (1998) Neotectonic intersection of the Aegean and Cyprus tectonic arcs: extensional and strike-slip faulting in the Isparta Angle, SW Turkey. Tectonophysics 298:103-132

Görgün E, Zang A, Kalafat D, Kekovalı K (2014) The 10 June 2012 Fethiye Mw 6.0 aftershock sequence and its relation to the 24-25 April 1957 Ms 6.9-7.1 earthquakes in SW Anatolia, Turkey. J Asian Earth Sci 93:102-112

Guidoboni E, Comastri A (2005) Catalogue of earthquakes and tsunamis in the Mediterranean area from the 11 th to the 15 th century. INGV-SGA, Bologna

Guidoboni E, Ebel JE (2009) Earthquakes and tsunamis in the past: a guide to techniques in historical seismology. Cambridge University Press, Cambridge. ISBN-13: 9780521837958

Gürer A, Bayrak M, Gürer ÖF (2004) Magnetotelluric images of the crust and mantle in the southwestern Taurides, Turkey. Tectonophysics 391(1):109-120

Hall J, Aksu AE, Yaltırak C, Winsor JD (2009) Structural architecture of the Rhodes Basin: a deep depocentre that evolved since the Pliocene at the junction of Hellenic and Cyprus Arcs, eastern Mediterranean. Mar Geol 258:1-23

Hall J, Aksu AE, Elitez I, Yaltırak C, Çifçi G (2014) The Fethiye-Burdur Fault Zone: a component of upper plate extension of the subduction transform edge propagator fault linking Hellenic and Cyprus Arcs, Eastern Mediterranean. Tectonophysics 635:80-99

Hartzell SH, Heaton TH (1983) Inversion of strong ground motion and teleseismic waveform data for the fault rupture history of the 1979 Imperial Valley, California, earthquake'. Bull Seism Soc Am 73:1553-1583

Huguen C, Mascle JE, Chaumillon J, Woodside M, Benkhelil J, Achim K, Volkonskaia A (2001) Deformational styles of the eastern Mediterranean Ridge and surroundings from combined swath mapping and seismic reflection profiling. Tectonophysics 343:21-47 
Irmak S (2013) Focal mechanisms of small-moderate earthquakes in Denizli Graben (SW Turkey. Earth Planets Space 65:943-955

Jolivet L, Faccenna C (2000) Mediterranean extension and the Africa-Eurasia collision. Tectonics 19:1095-1107

Kalafat D, Kekovalı K, Güneş Y, Yılmazer M, Kara M, Deniz P, Berberoğlu M (2009) A catalogue of source parameters of moderate and strong earthquakes for Turkey and its surrounding area (1938-2008). Boğaziçi Üniversitesi Report, Istanbul, Turkey

Kikuchi M, Kanamori H (1991) Inversion of complex body waves-III. Bull Seism Soc Am 81:2335-2350

Kikuchi M, Yagi Y, Yamanaka Y (2000) Source process of Chi-Chi, Taiwan earthquake of September 21, 1999 inferred from teleseismic body waves. Bull Earthq Res Inst Univ Tokyo 75:1-13

Kiratzi A, Louvari E (2003) Focal mechanisms of shallow earthquakes in the Aegean Sea and the surrounding lands determined by waveform modelling: a new database. J Geodyn 36(1-2):251-274

Kissel C, Poisson A (1986) Etude paléomagnétique préliminare des formations néogénes du bassin d'Antalya (Taurides occidentales, Turquie). Comptes Rendus de I'Académie des Sciences de Paris 302:711-716

KOERI (2012) http://www.koeri.boun.edu.tr/sismo/indexeng.htm. Visited 19 June 2012

Kohketsu K (1985) The extended reflectivity method for synthetic near-field seismograms. J Phys Earth 33:121-131

Kontogianni VA, Tsoulos N, Stiros SC (2002) Coastal uplift, earthquakes and active faulting of Rhodes Island (Aegean Arc): modeling based on geodetic inversion. Mar Geol 186:299-317

Kreemer C, Chamot-Rooke N (2004) Contemporary kinematics of the southern Aegean and the Mediterranean Ridge. Geophys J Int 157:1377-1392. doi:10.1111/j.1365-246X.2004.02270.x

Lawson CH, Hanson RJ (1974) Solving least squares problems. Prentice-Hall, Englewood Cliffs

Le Pichon X, Nicolas L, Angelier J, Renard V (1982) Strain distribution over the east Mediterranean ridge: a synthesis incorporating new Sea-Beam data. Tectonophysics 86:1-3, 243-255, 259-274

Leite O, Mascle J (1982) Geological structures on the south Cretan continental margin and Hellenic Trench (eastern Mediterranean). Mar Geol 49:199-223

Lekkas E, Papanikolaou D, Sakellariou D (2000) Neotectonic map of Greece: Rhodos Sheet. Tectonic Committee of the Geological Society of Greece, Athens

Mascle J, Martin L (1990) Shallow structure and recent evolution of the Aegean Sea; a synthesis based on continuous reflection profiles. Mar Geol 94:271-299

McClusky S, Balassanian S, Barka A, Demir C, Ergintav S, Georgiev I, Gurkan O, Hamburger M, Hurst K, Kahle H, Kastens K, Kekelidze G, King R, Kotzev V, Lenk O, Mahmoud S, Mishin A, Nadariya M, Ouzonis A, Paradissis D, Peter Y, Prilepin M, Reilenger R, Sanli I, Seeger H, Tealeb A, Toksöz MN, Veis G (2000) Global positioning system constraints on plate kinematics and dynamics in he eastern Mediterranean and Caucasus. J Geophys Res 105:5695-5719

McKenzie D (1972) Active tectonics of the Mediterranean region. Geophys J Roy Astron Soc 30:109-185

Meade BJ, Hager BH, Mcclusky SC, Reilinger RE, Ergintav S, Lenk O, Barka A, Özener H (2002) Estimates of seismic potential in the Marmara Sea region from block models of secular deformation constrained by global positioning system measurements. Bull Seismol Soc Am 92:208-215

Micheal AJ (1991) Spatial variations of stress within the 1987 Whittier Narrows, California, aftershock sequence: new techniques and results. J Geophys Res 96:6303-6319

Okay AI, Tüysüz O (1999) Tethyan sutures of northern Turkey. In: Durand B, Jolıvet L, Horvath E, Seranne M (eds) The Mediterranean Basins: tertiary extension within the Alpine Orogen. Geological Society London Special Publications 156, pp 475-515

Över S, Özden S, Pınar A, Yılmaz H, Ünlügenç UC, Kamaci Z (2010) Late Cenozoic stress field in the Cameli Basin, SW Turkey. Tectonophysics 492(1-4):60-72

Över S, Hüseyin Y, Pınar A, Özden S, Ünlügenç UC, Kamaci Z (2012) Plio-Quaternary stress state in the Burdur Basin. Tectonophysics, SW-Turkey. doi:10.1016/j.tecto.2012.12.009

Papadopoulos GA (2001) Tsunamis in the East Mediterranean: a catalogue for the area of Greece and adjacent seas. In: Proceedings of the Joint IOC-IUGG international workshop. Tsunami Risk Assessment beyond 2000: theory, practice and plans, Moscow, Russia

Papazachos B (1996) Large seismic faults in the Hellenic Arc. Ann Geofis 395:891-903

Papazachos B, Delibasis N (1969) Tectonic stress field and seismic faulting in the area of Greece. Tectonophysics 73:231-255

Papazachos BC, Comninakis PE, Karakaisis BG, Karakostas BG, Papaioannou CA, Papazachos CB, Scordilis EM (2000) A catalog of earthquakes in Greece and surrounding area for the period 550 BC1999. Geophysics Laboratory, University of Thessaloniki, Thessaloniki

Piper JD, Gürsoy AH, Tatar O, Beck ME, Raoa A, Koçbulut F, Mesci BL (2010) Distributed neotectonic deformation in the Anatolides of Turkey: a palaeomagnetic analysis. Tectonophysics 488:31-50 
Pondrelli S, Morelli A, Ekström G, Mazza S, Boschi E, Dziewonski AM (2002) European-Mediterranean regional centroid-moment tensors: 1997-2000. Phys Earth Planet Int 130:71-101

Reilinger R, McClusky S, Vernant P, Lawrance S, Ergintav S, Çakmak R, Özener H, Kadirov F, Guliev I, Stepanyan R, Nadariya M, Hahubia G, Mahmoud S, Sakr K, ArRajehi A, Paradissis D, Aydrus A, Prilepin M, Guseva T, Evren E, Dmitrotsa A, Filikov S, Gomez F, Ghazzi R, Karam G (2006) GPS constraints on continental deformation in the Africa-Arabia-Eurasia continental collision zone and implications for the dynamics of plate interactions. J Geophys Res 111:B05411. doi:10.1029/ 2005JB004051

Sbeinati MR, Darawcheh R, Mouty M (2005) The historical earthquakes of Syria: an analysis of large and moderate earthquakes from 1365 B.C. to 1900 A.D. Ann Geophys 48(3):347-435

Scherbaum F (1994) Modelling the Roermond earthquake of 1992 April 13 by stochastic simulation of its high-frequency strong ground motion. Geophys J Int 119:31-43

Şengör AMC, Yılmaz Y (1981) Tethyan evolution of Turkey: a plate tectonic approach. Tectonophysics 75:181-241

Şengör AMC, Görür N, Şaroğlu F (1985) Strike-slip faulting and related basin formation in zones of tectonic escape: Turkey as a case study. In: Biddle KT, Christie-Blick N (eds) Strike-slip deformation, basin formation and sedimentation. Society of Economic Mineralogist and Paleontologists Special Publication 37, pp 227-264

Shaw B, Jackson J (2010) Earthquake mechanisms and active tectonics of the Hellenic subduction zone. Geophys J Int 181:966-984. doi:10.1111/j.1365-246X.2010.04551.X

Snoke JA, Munsay JW, Teague AG, Bollinger GA (1984) A program for focal mechanism determination by combined use of polarity and SV-P amplitude ratio data. Earthq Notes 55(3):15

Soloviev SL, Solovieva ON, Go CN, Kim KS, Shchetnikov NA (2000) Tsunamis in the Mediterranean Sea 2000 B.C.-2000 A.D. In: Advances in natural and technological hazards research, vol 13. Kluwer, Dordrecht

Tan O, Taymaz T (2006) Active tectonics of the Caucasus: earthquake source mechanisms and rupture histories obtained from inversion of teleseismic body waveforms, Post-collisional Tectonics and Magmatism in the Mediterranean Region and Asia Geological Society of America, Special Paper 409, pp 531-578. doi:10.1130/2006.2409(25)

Taymaz T, Westaway R, Reilinger R (2004) Active faulting and crustal deformation in the Eastern Mediterranean Region. Tectonophysics 391:1-9. doi:10.1016/j.tecto.2004.07.005

Ten Veen JH (2004) Extension of Hellenic forearc shear zones in SW Turkey: the Pliocene-Quaternary deformation of the Esen Çay Basin. J Geodyn 37:181-204

Ten Veen JH, Kleinspehn KL (2003) Incipient continental collision and plate-boundary curvature: late Pliocene-Holocene transtensional Hellenic forearc, Crete, Greece. J Geol Soc Lond 160:161-181

Ten Veen JH, Boulton SJ, Alçiçek MC (2009) From palaeotectonics to neotectonics in the Neotethys realm: the importance of kinematic decoupling and inherited structural grain in SW Anatolia (Turkey). Tectonophysics 73:261-281

Titschack J, Joseph N, Fietzke J, Freiwald A, Bromley RG (2013) Record of a tectonically-controlled regression captured by changes in carbonate skeletal associations on a structured island shelf (midPleistocene, Rhodes, Greece). Sediment Geol 283:15-33

Van Hinsbergen DJJ, Langeris CG, Meulenkamp JE (2005) Revision of the timing, magnitude and distribution of Neogene rotations in the western Aegean region. Tectonophysics 396:1-34

Verhaert G, Similox-Tohon D, Vandycke S, Sintubin M, Muchez PH (2006) Different stress states in the Burdur-Isparta region (SW Turkey) since Late Miocene times: a reflection of a transient stress regime. J Struct Geol 28:1067-1083

Woodside J, Mascle J, Huguen C, Volkonskaia A (2000) The Rhodes Basin, a post-Miocene tectonic trough. Mar Geol 165:1-12

Yagi Y (2004) Source rupture process of the 2003 Tokachi-oki earthquake determined by joint inversion of teleseismic body wave and strong ground motion data. Earth Planet Space 56:311-316

Yagi Y, Kikuchi M, Nishimura T (2003) Co-seismic slip, post-seismic slip, and largest aftershock associated with the 1994 Sanriku-haruka-oki, Japan, earthquake. Geophys Res Lett 30(22):2177. doi:10.1029/ 2003GL018189

Yagi Y, Mikumo T, Pacheco J, Reyes G (2004) Source rupture process of the Tecoma'n, Colima, Mexico earthquake of 22 January 2003, determined by joint inversion of teleseismic body-wave and nearsource data. Bull Seismol Soc Am 94:1795-1807

Yamaji A (2000) The multiple inverse method: a new technique to separate stresses from heterogeneous fault-slip data. J Struct Geol 22:441-452

Y1lmaztürk A, Burton PW (1999) Earthquake source parameters as inferred from the body waveform modeling southern Turkey. Geodynamics 27:469-499 
Yolsal-Çevikbilen S, Taymaz T (2012) Earthquake source parameters along the Hellenic subduction zone and numerical simulations of historical tsunamis in the Eastern Mediterranean. Tectonophysics 536-537:61-100

Yoshida S (1992) Waveform inversion for rupture process using a non-flat seafloor model: application to 1986 Andreanof Island and 1985 Chile earthquake. Tectonophysics 211:45-59

Yoshida S, Koketsu K, Shibazaki B, Sagiya T, Kato T, Yoshida Y (1996) Joint inversion of near- and farfield waveforms and geodetic data for the rupture process of the 1995 Kobe earthquake. J Phys Earth 44:437-454 